\title{
Yeni Kapitalizm Kültüründe Otomobil Reklamları: Audi ve Skoda Reklamları Örneği
}

\author{
Nilüfer Pınar Kılıç ${ }^{1}$
}

Öz

\begin{abstract}
Yaşam tarzının meta haline geldiği ve göstergelerin tüketilmeye bașlandığı yeni kapitalizm kültüründe reklam içerikleri, marka değeri olușturulması, yükseltilmesi ve farklıııkların belirgin hale getirilmesinde kullanılmakta ve böylece tüketici, kullandığı ürünün diğerlerinden farklı olduğu algısını yaşayarak kendini farklı hissetmektedir. Tüketim kültürünün temel öğelerinden biri olan otomobiller de gösterge değeri ve bireyin kimliğiyle ilişkilendirilerek reklamlarda sunulmaktadır. Esnek üretimle birlikte aynı üretici grup, farklı kitlelere üretim yapmakta ve reklamlarda da bu farklıı̆ı belirginleştirmektedir. Betimleyici tarzda yapılandırılan bu çalışmada aynı üretici gruba ait Skoda ve Audi marka otomobillerin 40 reklamı içerik analizi tekniğiyle incelenerek söz konusu otomobiller arasındaki farkın hangi göstergelerle oluşturulduğu çözümlenmeye çalışılmıştır. Reklamlarda Audi marka otomobillerin aristokrat sınıfın elde edebileceği değerde, kimlik ve yașam tarzı oluşumunda bir araç olarak bireyselliği önceleyen bir fetiş nesnesi olarak sunulduğu tespit edilmiştir. Skoda marka otomobillerin reklamlarında ise orta sınıf gençler ve ailelerden oluşan rasyonel tüketiciye hitap ettiği, karlııı̆ın, işlevselliğin, kolektifliğin ve ataerkil değerlerin ön planda olduğu görülmüştür.
\end{abstract}

Anahtar Kelimeler: Yeni Kapitalizm Kültürü, Tüketim, Kültür Endüstrisi, Reklam, Otomobil Reklamları.

\section{Automobile Advertisement in the Culture of the New Capitalism: The Case of the Advertisements of Audi and Skoda}

\begin{abstract}
In the culture of the new capitalism, where lifestyle has been commodified and signs are consumed, the content of advertisements is used for the creation and strengthening of a brand value and to crystallize differences so that the consumer feels that the product it consumes, hence the consumer itself, is much different from other products. Automobiles, which are fundamental elements of consumption culture, are also presented in advertisements through association with their signifying value and the identity of the individual. With the introduction of flexible production, the same manufacturing group produces products for different groups of people and crystallize such differences in their advertisements. This study, which is based on a descriptive analysis, will focus on 40 advertisements of Skoda and Audi automobiles which belong to the same manufacturing group and will try to show through what signs the difference between the automobiles has been created. Through the analysis of the advertisements, it has been determined that Audi automobiles are presented as an object of fetish having a value which could only be afforded by aristocratic classes and which prioritizes individualism as a means of creating an identity and a way of life. In the advertisements of Skoda automobiles, on the other hand, it has been observed that the brand appeals to a group of rational consumers consisting of middle class youth and families elevating the values of profitability, functionality, collectivity and patriarchy.
\end{abstract}

Keywords: Culture of New Capitalism, Consumption, Culture Industry, Advertisement, Automobile Advertisements.

1 Arş. Gör., Ankara Üniversitesi Illetişim Fakültesi. 


\section{Giriș}

Y irminci yüzyıl kapitalizminde odak noktası üretimden tüketime kaymış; tüketicilerin kendi başlarına karar alamadıkları, sahte intiyaçların yaratıldığı, sembollerin tüketildiği bir kültür oluşmuştur. Esnek üretim sistemiyle birlikte üretilen ürünlerin tüketiciye göre farklılaştığı bu kültürde aslında ürünler arasındaki ayrımlar, gerçek farklıııkları yansıtmak yerine tüketicilerin sınıflandırılmasına hizmet etmekte ve zihinlere kazınarak yaygınlaşmaktadırlar. Her tüketicinin kendi belirlenmiş düzeyine uygun davranmasını gerekli kılan bu kültürde ürünün avantajları ya da dezavantajları olarak tartışılan şeyler de tercih etme olanağı görüntüsünü yaratmakta ve rekabeti sürekli kılmaktadır. Sadece farklı üreticiler için değil aynı şirkete ait koleksiyonları oluşturan ucuz ve daha pahalı ürünler arasındaki fark için de geçerli olan bu durum otomobillerde silindir sayısına, motor hacmi, ileri teknoloji ürünü cihazların patent bilgilerine indirgenmektedir (Adorno ve Horkheimer, 2010: 165-166).

Sennet (2011) ürünler arasındaki farklılıkları otomobil örneği üzerinden 'altın kaplama' ve 'marka değerinin yükseltilmesi' kavramları ile açıklamaktadır. Sennett'e göre otomobil çeşitleri arasındaki \%10'luk içerik farkı, fiyatta \%100'lük bir fark haline gelmektedir. İmalatçılar ürünü belirli bir markaya çevirmek için aynı montaj hattında üretilen ürünlerde ufak, yüzeysel değişiklikler yapmaktadırlar. Altın kaplama adı verilen bu değişikliklerle, temelde standartlaştırımış şeylerde değişikliklerin değeri abartılarak yüzey önemli hale gelmektedir. Böylece marka tüketiciye ürünün kendisinden daha değerli görünmektedir (Sennett, 2011: 91-92). Aslında çok farklı şeyleri tükettiğini düşünen tüketici değeri yükseltilmiş markaları tüketmektedir. Yaratılan değer farklarının gerçek farklarla ya da ürünün anlamıyla ilgisinin olmadığı bu durum reklamlarla pekiştirilmektedir. Farklılıkları yüceltmek maksadıyla üretilen reklamlar sayesinde tüketici, kullandığı ürünün diğerlerinden farklı olduğu algısını yaşamakta ve ürünü tüketerek kendini farklı hissetmektedir.

Otomobiller arasındaki imgesel farklara odaklanan bu çalışmada Volkswagen gruba ait iki markanın reklamları incelenmiştir. Toplamda 107 fabrikası bulunan Volkswagen grubunun her fabrikasındaki montaj hattı esnek üretime izin vermese de örneğin Hindistan'daki Aurangabad fabrikasında Volkswagen Jetta, Skoda Octavia, Skoda Superb, Skoda Yeti, Audi A4, Audi A6, Audi Q3, Audi Q5 ve Audi Q7 markaları üretilmektedir². Grubun reklamlarında aynı fabrikada üretilebilen markaları nasıl farklılaştırdığını ve bu farklıı̆̆ı hangi göstergelerle verdiğini anlamayı amaçlayan bu çalışmada Skoda ve Audi markalarına ait 40 reklam incelenmiştir. Otomobillerin birim üretim maliyetlerinin belirlenememesi nedeniyle ekonomik yönden kıyaslama yapılamayan çalışmada reklamların içeriği analiz edilerek sözü edilen markalarda hangi temaların ön plana çıkarıldığı ve tüketicileri nasıl tüketime yönlendirdikleri betimlenmeye çalışılmıştır.

\section{Büyük Anlatıların Ortadan Kalktığı Yeni Bir Toplum Türü}

Tüketim ekonomik olmasının yanı sıra, aynı zamanda toplumsal, psikolojik ve kültürel bir olgudur (Bocock, 2009: 10). Tüketim çalışmalarına yol gösteren Frankfurt Okulu teorisyenlerinden Adorno ve Horkheimer (2010: 162-222) kapitalizmin kendini yeniden üretmesini kültür ile ilişkilendirerek açıklamaktadırlar. 'Kültür endüstrisi' kavramı ile betimledikleri sistemde kültür, fabrikaya giren hammadde gibi imal edilmektedir. Ortak bir payda yaratılmaya çalışılan ve ürünlerin basitleştiği kültürün üretiminde halkın hiçbir etkisi bulunmamaktadır. Kültür endüstrisinde, yapay gereksinimler ve ihtiyaçlar da imal edilerek, eblehleşmiş, manipüle edilmiş tüketiciye ulaştırılmaktadır. Taklit olanı mutlak olanın yerine koyan kültür endüstrisi, "durmaksızın vaat ettiği şeylerle tüketicisini” aldatmaktadır. Kültür endüstrisiyle görünür kılınan tüketim eleştirisi 1960’lı

2 http://www.volkswagenag.com/content/vwcorp/content/en/the_group/production_plants.html (03.01.2015). 
yıllardan sonra tüketimin artmasıyla artış göstermiş ve 1990'। yıllarda postmodern düşünürlerle birlikte göstergeler üzerine yoğunlaşmıştır.

Fordist sistemde yaşanan sorunların belirginleşmeye başlamasıyla 1960'। yılların ortalarında daha esnek bir üretime yönelinmiş, üretim sektörler arası geçişkenliğe izin verecek şekilde düzenlenmiştir (Harvey, 2010: 164). Yönetici iktidarın sermaye iktidarına geçişi ve küreselleşmesi, yatırımcıların kısa vadeli sonuç istemeleri, dolayısıyla yenilik isteyen sabırsız sermaye baskısı bilgisayar teknolojilerindeki gelişimle birleşince yeni bir sistem ve kültür yaratmıştır (Sennett, 2011: 30-34). Esnek üretimle birlikte farklı tüketici kategorilerine göre yapılan üretim, tüketimin bireyselleşmesini getirmiş, aşırı üretim beraberinde aşııı tüketimi de getirmiştir (Dağtaş ve Dağtaş, 2009: 44-45). Jameson bu durumu 1960'larda yaşanan dönüşümlerin ardından geç kapitalist bir döneme geçtiğimizi belirterek açıklamaktadır. Jameson'a göre (1994: 59-116) ulus içerisinde piyasa kapitalizminin yaşandığı ilk dönemden, sermayenin ulus aşırı olmaya çalıştığı tekelci kapitalizme ve tüketici kapitalizmine dönüşmüş olan sistemde son aşama olarak geç kapitalizm aşamasına gelinmiştir. 1960'larda yaşanan; üretim tekniklerinde standartlaşma, medyanın parçalanması, moda döngüsünün hızlanması, üslubun çeşitlenmesi, gerçekliğin imgeye dönüşmesiyle, Marksizm gibi büyük anlatıların ortadan kalktığı yeni bir toplum türü ortaya çıkmıştır Postmodernizm, postfordizm, geç kapitalist dönem, yeni kapitalizm, tüketim toplumu gibi farklı kavramlarla ifade edilen bu yeni dönemde ortak vurgunun "tüketim ve kültür"de olduğu görülmektedir.

Günlük hayat pratikleriyle düşünüldüğünde tüketimin insanla birlikte var olduğu söylenebilmektedir. Bu yeni dönemde ise toplumun bütün üyelerinin tüketmesinin dışında kadın ve erkeklerin topluma tüketici olarak entegre edildiği, her kültür maddesinin bir meta haline geldiği veya pazar mantığına bağımlı kılındığı bir tüketici kültüründen söz edilmektedir (Bauman, 2003: 198; Bauman; 2010b: 92). Kapitalizmin hala yerinde durduğu, toplumsal olan her şeyin küçüldüğü, becerilerin tükenerek yeni bir şey yapabilme haline geldiği ve potansiyel kabiliyetin arandığı, başarısızlığın nesnelleştirildiği (Sennett, 2011: 55, 63, 72 ) bu ortamda tüketim önemli hale gelerek tüm yaşamı kuşatmış, bireyde ve toplumsal anlamda dönüşümlere, değişimlere yol açmıştır.

Tüketim kültürünün yol açtığı dönüşümlerden ilki yaşam tarzının bir tasarı ve meta haline gelmesi olarak ifade edilebilir. Tüketicinin beğeni üslubunun işaretleri olarak tanımlanabilecek yaşam tarzı (Featherstone, 1996: 41) geç kapitalist dönemin getirdiği tüketici kültüründe bir meta haline gelerek ön plana çıkmıştır. Bireyin bireyselliğini ve farklıı̆̆ını temsil eden yaşam tarzı, tüketim gruplarını da belirlemektedir. Tüketim mallarını alarak ve sergileyerek toplumsal ayrıcalık kazanan birey, sunulan yaşam tarzı bağlamında tasarı halini almaktadır (Baudrillard, 2008). Bauman'a göre (2003: 198), tüketici gereksinimleri arasına yaşam tasarısı gereksinimi de eklenmiştir. Yaşam tasarısı artık, "belli bir amaca yönelik satın almaların zaman dizisi şeklinde düzenlenmektedir" Tüketilen ürünlerin ifade ettiği yaşam tarzının ihraç edildiği (Ritzer, 2011: 68) kültürde nesnelerin metalaşması ve dolayısıyla duyguların sönmesi insan bedenleri için de geçerlidir (Jameson, 1994: 71). Yeni kapitalizm kültüründe "tüketen" beden, üretme kapasitesi yerine tüketme kapasitesi ile değerlendirilmektedir. Birey, tüketim mallarına sahip olma ile bireyselleşmiş ve kendi kendine yeterli olabileceği, ne tür bir hayat yaşamak istediğiyle ilgili kararların kendine bağlı olduğu, başarısızlıkta kendini suçlaması gerektiği (Bauman, 2010a: 43) mitine inanmıştır. Bireyselliğin ve farklılığın teşvik edildiği tüketim kültüründe birey maddi olarak sahip olduğu, tükettiği ürünlerle sınıflanırken, Ewen'ın (Aktaran Dağtaş, 2009: 63-65) da belirttiği gibi seçilen tarz ile sınıf edinme yanılsaması görünür kılınmıştır. Öte yandan Bourdieu, sınıf, kültürel sermaye gibi toplumsal yapının devamlıı̆ının toplumsal yapılarla yeniden üretildiğini ve tüketim alışkanlıklarının da bu yapılardan etkilendiğini açıklamaktadır. Bourdieu’ya göre (1996: 
175-176) beğeniler toplumsal uzamda kapladığımız konumlara göre belirlenmektedir. Tek başına ekonomik sermaye ile belirlenemeyecek olan sınıfsal yapıların beğenileri ayrışmaktadır.

İkinci olarak tüketim kültürünün içinde bulunduğu kapitalist sistem, pazar içerisinde gelişen hizmet sektöründe yüksek maaşlarla çalışan yeni üst-orta sınıf yaratmıştır. Bourdieu'nun (1996: 152) kültürel sermayede dönüşüme yol açabileceğini belirttiği bir grup meslek üyesi bu grupta yer almaktadır. Çeşitli danışmanlık hizmetleri (psikoloji, mesleki rehberlik, konuşma terapisti, evlilik danışmanlığı, diyetisyen vd.), eğitsel meslekler (kreş yöneticileri, gençlik liderleri, kültürel program organizatörleri) ve sunum ve temsili içeren meslekler (tur organizatörleri, hostesler, turist rehberleri, radyo ve televizyon sunucuları, yarışma programları sunucuları, basın ataşeleri, halkla ilişkiler çalışanları vd.) toplumsal yeniliklerin yayılmasını sağlamaktadırlar. Yaşam tarzlarının yayılmasında önemli rol oynayan yeni kültür aracılarını Featherstone (1996: 132) "reklam, pazarlama, tasarım, moda, ticari sanat, mimari ve gazetecilik" ve bunlarla ilişkili diğer alanlarda çalışanlar olarak nitelemektedir. Kamunun yeni üsluplar ve beğeniler konusunda eğitilmesinde önemli rol oynayan kültür aracıları neyin nasıl tüketilmesi gerektiği konusunda örnek oluşturmakta ve bireyleri yönlendirmektedirler.

Üçüncü olarak, tüketim kültürü içerisinde ihtiyaçların tanımı değişmiş, bu kültür nesneler yerine değerleri hedef almıştır (Bocock, 2009: 71). Tüketimin sürekliliğinin sağlanabilmesi maksadıyla nesnenin "görünüşteki kullanım değeriyle gerçek kullanım değeri arasındaki farkın anlaşımaması için yeni vaatler (Bauman, 2003: 197)" sunularak yapay intiyaçlar üretilmektedir. İhtiyaçların sahteleştirilmesi, seri üretilen mallar arasında kıt olan bir malın bulunabileceği yanılsamasının yaratılması, varlıkların gerçek kullanım amaçlarının dışında çağrışımlarla doğasının gizlenmesi ile tüketiciler uyarılmakta (Sennett, 2002: 194) ancak intiyaçlar ve intiyaçların giderilmesi arasındaki geleneksel ilişkinin de tersine çevrilmesiyle (Bauman, 2010b: 94) hiçbir intiyaç tamamen doyurulmuş olmamaktadır. Baudrillard'a göre (2008: 80) tüketim kültürünün dayattığı sahte intiyaçlara, "toplumun ve tarihin şekillendiremediği hiçbir sahici ihtiyaç ve istekle karşı" koymak mümkün değildir. Öte yandan pazarın yeni intiyaçları doğal olandan ayırt edilemeyecek hale getirmesi ile yeni mallar vazgeçilmez hale gelmekte ve kendi zorunluluklarını yaratmaktadırlar.

İhtiyaçların yapaylığının tartışıldığı bu ortamda gerçeklik algısı da değişmiştir. Günümüzde imajlar dünyasının ve kitle iletişim araçlarının fantazmagoryasının hâkimiyetinin artması sonucunda birey gerçeklik duygusunu yitirmektedir (Dağtaş ve Dağtaş, 2009: 59). Tüketim kültüründe birey ürünlerin yerine göstergeleri tüketmektedir. Metaların hangi bağlamda tüketildiğinin önemi yoktur. Önemli olan değerler sistemi açısından simgesel anlamlara sahip olan metaların tüketilmiş olmasıdır. Yeni kapitalizm kültüründe, tüketicinin satın aldığı şey ile "gerçek" arasındaki bağlantı koparak meta, Baudrillard'ın (1997) "hiperreel” olarak tanımladığı şeye, yani tüketicilerin gereksinimleri ile hiç ilgisi bulunmayan bir göstergeler/semboller alanına dönüşmüştür. Bocock'a göre (1997: 117) de tüketim malları semboller olarak satılmakta ve kendi gerçekliklerini oluşturmaktadırlar.

\section{Tüketim Kültürünün İksiri: Reklam}

Baudrillard'a göre (2008: 41), bütün toplumlar her zaman zorunlu harcamalar ötesinde har vurup harman savurmuş, harcamış ve tüketmiştir. Çünkü toplum gibi birey de sadece var olmadığını, ama yaşadığını aşırı, gereğinden fazla bir tüketimle hissetmektedir. Yani tüketim, yaşamı devam ettirme yolunda bir araç olmaktan çıkmış, kendi başına bir amaç haline gelmiştir. Günümüzde farklılaşmış mallar, nesneler ve göstergelerin sahiplenilişi tüm toplumun iletişime geçmek için kullandığı şeydir. "Tüketim göstergelerin düzenlenmesini ve grubun bütünleşmesini güvence altına alan bir sistemdir. Dolayısıyla tüketim hem bir ahlak (bir ideolojik değerler sistemi) hem de bir iletişim sistemi ve bir değiş tokuş yapısıdır (Baudrillard, 2008: 91)." Tüketici pazarı tüketiciyi 
kendine bağımlı hale getirme yetisi ile günlük işler yardımsız yapılamayacak kadar güçleşmiştir. Söz konusu pazar bağımlıı̆̆ı toplumsal becerilerin yok edilmesi ile bağlantılıdır (Bauman, 2003: 195).

Küresel anlamda tüketimin yaşandığı bu dönemde, herkes daha fazla tüketme baskısı altında kalmakta ve bu yolda bireyler kendilerini tüketim ve emek piyasalarında metalara dönüştürmektedirler (Bauman, 2010a: 53). Mal ve hizmetlerin tüketilmesini sağlayan ortamların baş döndürücü bolluğu sayesinde birey sık sık kendini tüketime adanmış ortamlarda bulmaktadır. Evlerimizin bile "tele-pazarlama, süprüntü postalar, kataloglar, evden alışveriş kanalları ve siber mağazaların işgali altında" (Ritzer, 2011: 15) tüketim aracı haline geldiği ortamda birey tüketme baskısı altında yaşamak durumunda kalmaktadır. Tüketme baskısının bu kadar yoğun olduğu tüketim kültüründe, reklamlar tüketim itkisinin oluşturulmasında bir araç konumunda yer almaktadır.

Rekabetçi sistemde pazardaki tüketiciye yol göstermek, tercih yapılmasını kolaylaştırmak, "bilinmeyen tedarikçilerin mallarını ilgili tüketiciye satabilmelerine yardımcı" olmak (Adorno ve Horkheimer, 2010: 215) gibi toplumsal bir hizmet görmüşlerdir. Yani kapitalizm kültüründe ise reklam metinleri ürün hakkında bilgi veren metinlerden yaşam tarzı sunan metinlere doğru evrilmiş, ikna etmek ve arzu yaratmak için üretilmeye başlamışlardır (Aygün Cengiz, 2009: 6869). Günümüzde reklamlar ürünün fayda ve kalitesi yerine artık imaj değerlerine seslenmekte, "dağıtılan dikkati yeterli süre belli bir odakta tutarak istenen davranışın oluşmasını sağlamaya çalışmaktadırlar (Bauman, 2000: 249)".

Adorno ve Horkheimer'in (2010: 215) kültür endüstrisinin yaşam iksiri olarak nitelendirdikleri reklam, tüketicilerin tepkilerinin imal edilmesini sağlamaktadır. Bocock (2009: 88) çocukların dünyaya tüketme arzusuyla gelmediklerini, tüketici olmayı öğrendiklerini belirtmektedir. Tüketim kültüründe bireylerin tüketici olmalarının öğretildiği en önemli mecralardan biri reklam olarak karşımıza çıkmaktadır (Aygün Cengiz, 2009: 16). Reklamların sadece mesajların "saydam taşıyıcısı olduğuna inanmak aldatıcı reklamcılık mitolojisinin bir parçasıdır" (Williamson, 2000: 15). Nesnelerin kullanım değerlerini arttırmanın yerine azaltan reklam, nesnelerin moda değerini arttırarak hızlı bir yenilenmeye tabi kılmakta ve zaman değerini azaltmaktadır. İnsana tek başına seslenmeyen, farklılaştırıcı ilişkisi içinde hedef alan ve intiyaçların koşullandırılması için üretilen reklamın anlamı yoktur, sadece anlamlandırmalar getirmektedir (Baudrillard, 2008: 45, 73, 81, 104). Sahte ihtiyaçların yaratılmasında ve sembollerin üretilip yaygınlaştırılmasında önemli bir yerde duran reklamlar sayesinde tüketici, göstergeleri tüketerek kimlik ve aidiyet sorununa çözüm üretmekte ve kendini bir statü grubuna konumlandırmaktadır.

\section{Otomobilde Flâneur}

İcat edildiği ilk yıllarda lüks tüketim nesnesi olan otomobil, seri üretimle birlikte gündelik yaşama dâhil edilmiştir. 1930'lu yılların endüstriyel kitle ürünü olarak daha geniş kesime ulaşmayı başarmışsa da 1950'li yıllara kadar gösterişli ve konforlu otomobil sadece üst tabakalarda yer alan bireylerin tüketebileceği bir konumda yer almaktadır. 1960'lı yıllarda kitlesel motorizasyonun başlamasının ardından kitle tarihindeki en süratli yayııımını gerçekleştirmeyi başaran otomobil, tüketim kültürünün temel öğelerinden biri haline gelmiştir (Aygün Cengiz, 2009: 48; Güneş, 2012: 214). Otomobil, bir "kral-nesne" ve bir "kılavuz şey" olarak ekonomiden söyleme kadar birçok alanda getirdiği düzenlemelerle gündelik hayatı yapılandırmaktadır. Mekânlar bile bu yapılandırmaya dâhil olmuş, garajı olan evler, alışveriş merkezleri, yollar otomobilleşen kültüre göre planlanmışlardır. Otomobiller toplumları ve mekânları şekillendirmesinin yanı sıra sahibinin toplumsal konumunu simgeleyerek salt bir ulaşım aracı olmaktan çıkmış, "modern yaşamın ve 
Modernizmin göstergelerini eleştiren Flâneur'ün, tüketim kültürünün yaşandığı 20. yüzyılda gezintilerini araçla yaparak kendini kalabalıklardan soyutladığı söylenebilmektedir (Güneş, 2012: 214, 227;). Fransızca da "avare gezinen" anlamını taşıyan flâneur kavramıyla Benjamin Pasajlar metninde bireyin modern toplumdaki konumunu sorgulamaktadır. Paris'te 19. yüzyılda yapılan geniş kaldıımlar ve pasajlar ile ortaya çıkan Flâneur, sığınağını kitlede arayan, kalabalıkların içinde kendini evinde hisseden bir figürdür. Kalabalıklar içinde tüketmeyen ve filozof edasıyla alışveriş yapanları izleyerek gezinen Flâneur, aslında kalabalık içinde terk edilmiş ve yalnız kişidir. Benjamin'in "Flâneur, işi gücü olmayan birinin kişiliğine bürünerek gezinir; böylece insanları birer uzman yapan işbölümünü deprotesto etmiş olur. Bunun yanı sıra, insanların iş güç peşinde koşuşturup durmalarını da protesto eder... Flâneur, kendini kaplumbağaların temposuna uydurmaktan hoşlanırdı. Eğer ona kalsaydı, ilerlemenin böyle adımlarla sürmesini isterdi" sözlerinden de anlaşıldığı üzere avare başıboş gezinen izlenimini veren Flâneur aslında dönemi eleştirmektedir. (2002: 148). Ancak günümüzün tiryaki yolcusu olan Flâneur'ün araç içinde yaşadığı teklik ve hızın kendisine yaşattığı "kendi hayatı üzerinde denetimi olduğu duygusu" bir yanılsamadan ibarettir. Bu durumun en önemli nedeni;

\footnotetext{
... Flâneur'ün yaya olarak sokaklarda değil, bir araç içinde (araçla bütünleşmiş olarak) yollarda gezinirken teknoloji sayesinde kazanmış olduğu yeni uzuvları ve özellikleri (gözleri yerine dikiz aynası, elleri yerine direksiyon, ayakları yerine tekerlekler, derisi yerine kaporta, kas gücü yerine gaz ve fren pedalları vs.) ile hareket etmesidir. Flâneur, eskiden çok katı mağazaların vitrinlerinden öteki mallar arasında bir mankene dönüşen kadın biçimi imgesine baktığı gibi, şimdi de arabasının camlarından dışarıya bakmaktadır (Aygün Cengiz, 2009: 59).
}

Mobilize olmuş Flâneur, "kendi kişiliğini, hız, estetik ve güç algısını otomobilinde yansıtmak istemekte" ve kendi aracını diğer araçlardan farklılaştırmak için çaba göstermektedir (Güneş, 2012: 227). "Mekanik uygarlığa ait olmanın bir göstergesi" olan otomobil, yaşam düzeyinin bir simgesi olarak örneğin "seri dışı bir otomobil" ile "toplumsal katmanın bir gösterge kategorisine erişmesine, diğer katmanlarla araya mesafe" konulmasına yardımcı olmaktadır (Baudrillard, 2008: 109, 137). Böylece tüketici otomobili aracılığıyla sınıfsal konumunu pekiştirmekte ve yaşam tarzını ve kimliğini sergilemektedir.

Tüketim kültürünün önemli bir nesnesi olarak otomobilin gösterge değeri, sergilenebilir oluşu ve bireyin kimliğiyle ilişkilendirilmesi reklamlarda da kendini göstermektedir. Sennet'in (2011: 92-93) ifadesiyle aynı üretim bandından çıkabilen otomobillerdeki içerik farkı çok az olsa da altın kaplama ile gösterge değeri yüceltilmekte ve bu durum reklamlara yansımaktadır. Kolayca tasarlanabilen ufak değişikler abartılarak yaratılan farkla önemli hale getirilen yüzey, tüketicinin tutkuyu deneyimlemesine olanak sağlamaktadır. Nesnenin ne olduğuna gösterilen dikkat azaltılarak ve bağlamsızlaştırma yoluyla çağış̧ırdıkları satılmaya çalışılmaktadır. Otomobil reklamlarında da odak noktası otomobilin ulaşım sağlama işlevinden uzaklaşarak manzaraya sürüş deneyimine kaymakta, otomobil yerine imgeler görünür olmaktadır.

\section{Yöntem}

Betimleyici olarak tasarlanan bu çalışmada aynı üretici grup tarafından üretilen ancak farklı tüketici gruplarına yönelik olan Skoda ve Audi marka otomobil reklamları analiz edilerek, otomobillerin neler çağrıştırdıkları, aynı üretici grubuna ait olmalarına rağmen farklıııkları nasıl verdikleri

3 Çevirenin notu. (Benjamin, 2002: 92) 
anlaşılmaya çalışımıştır. İki otomobil markasının farklı modelleri bulunmakla beraber, Audi marka otomobil fiyatları 72.286-1.066.188 TL, Skoda marka otomobil fiyatları 35.200-140.900 lira arasında değişmektedir ${ }^{4}$. Bu bağlamda seçilen marka otomobil reklamlarında Audi markasının kendini lüks tüketim ürünü olarak konumlandırdığı ve haz, bireysellik, yaşam tarzı, gösteriş gibi unsurlara daha fazla vurgu yaptığı, Skoda markasının ise orta sınıfa yönelik olarak sınıf atlama vaadi sunduğu varsayılmaktadır.

Araştıranın evreni, tüm Skoda ve Audi reklamlarıdır. Ancak firmanın hangi yılda kaç adet reklam yaptığı tespit edilememiştir. Bu nedenle örneklem seçiminde genellikle evren birimlerinin tam bir listesinin olmadığı durumlarda kullanılan olasılıklı olmayan örneklem tekniğine başvurulmuştur. Çalışma kapsamında örneklemin geniş tutulması maksadıyla 20 Audi, 20 Skoda reklamı incelenmiştir. Arama motorlarına commercial, advertisement, reklam, Audi, Skoda, anahtar terimleri girilerek elde edilen reklamlar arasından olasılıklı olmayan örneklem türlerinden biri olan uygunluk örneklemi tekniği ile 40 reklam belirlenmiştir. Yeni çıkan modelleri tanıtmak amacıyla hazırlanan tanıtım videoları çalışma kapsamına dâhil edilmemiştir. Öte yandan belirlenen reklamların hangi tarih aralığında yayınlandığı kesin olarak bilinememektedir. Arama motorlarına yüklenme tarihleri ve reklamlarda gösterilen otomobil modelleri temel alındığında 2007-2013 yılları arasında üretilen reklamlar oldukları tahmin edilmektedir.

Çalışmada farklıııkların hangi göstergelerle verildiğinin tespiti amaçlandığından reklamlar içerik analizi tekniği ile analiz edilmiş ve iki çözümleme birimi oluşturulmuştur; süre, renk, reklamlarda arabanın görünmesi gibi fiziksel birimler ve tematik birimler. Kullanılan örneklem belirleme tekniği ile kestirimsel istatistik elde edilememesi ve sadece genelleme yapılabilmesi (Atabek ve Atabek, 2007: 11) nedeniyle bu çalışmada elde edilen sonuçlar tüm otomobil reklamları için istatistiksel bir değer taşımamaktadır. Bulgu ve yorumlar başlığında reklam analizinde oluşturulan çözümleme birimlerinden fiziksel birimler açıklandıktan sonra oluşturulan temalar alt başlıklar halinde sıralanmıştır.

\section{Bulgu ve Yorumlar}

Analize dâhil edilen reklamların sürelerinin çeşitlilik gösterdiği görülmektedir. Her iki marka otomobil reklamları 25-86 saniye arası sürmektedir. En uzun süren reklam 86 saniye ile Skoda 1 reklamı iken, en kısa olan Audi 5 reklamıdır. Audi marka otomobil reklamlarının süresi ortalama 41.60 saniye iken, Skoda marka otomobil reklamlarının ortalama süresi 40.45 saniyedir. Her iki markanın süre ortalamalarına bakıldığında anlamlı bir fark olduğunu söylemek mümkün değildir.

Audi marka otomobil reklamlarının hiçbirisinde aracın özellikleri ve fiyatı belirtilmemiştir. Öte yandan Skoda otomobil reklamlarının 4 tanesinde fiyat, 6 tanesinde otomobilin fiziksel veya teknik özellikleri belirtilmiştir. Bu bağlamda Skoda marka otomobil reklamlarının Audi marka otomobil reklamlarına göre işlevsel sorulara daha fazla yanıt verdiği söylenebilmektedir.

Audi marka otomobil reklamlarında siyah, beyaz ve gümüş renkler hâkim olarak kullanılmıştır. Reklamlarda 7 otomobil siyah, 4 otomobil beyaz, 7 otomobil gümüş ve 1 otomobil kırmızı renkte görünmektedir. Skoda marka otomobil reklamlarına bakıldığında renk yelpazesinin daha geniş olduğu görülmektedir. Skoda marka otomobil reklamlarında 7 gümüş 3 beyaz, 4 kırmızı, 2 yeşil, 2 turuncu, 1 kahverengi ve 1 mavi renk görünmektedir. Ayrıca Skoda 6 reklamında otomobilin 2112 renk varyasyonuna sahip olduğu belirtilmekte ve reklam boyunca otomobil birçok renkte

4 Verilen fiyat aralıkları söz konusu markaların internet sitelerinden 12.09.2014 tarihinde alınmıştır. Model farkı gözetmeksizin en düşük ve en yüksek fiyatlara bakılmıştır. 
gösterilmektedir. Audi reklamlarında yoğun olarak görülen otomobil rengi gümüş ve siyahtır. Gümüş rengi parlaklığından dolayı dikkat çekmesi ile birlikte, parlaklığın ekonomik olarak altın gibi değerli taşlara da gönderme yapmaktadır. Lüks ve değerli olarak sunulan otomobil, aynı zamanda parlaklığın değişik coğrafyalardaki efsanelerle ilişkilendirildiğinde gümüş rengiyle efsaneleşen, ilahi aşk ve mutlulukla ilişkilendirilen bir nesne haline gelmektedir (Aygün Cengiz, 2005: 152153). Yine Audi reklamlarında kullanılan siyah renk, sınıfsal üstünlüğe, aristokrasiye gönderme yapmaktadır. Skoda reklamlarında dikkat ve değer belirtisi olarak gümüş rengi kullanılsa da siyah renk kullanılmamıştır. Audi'nin özellikle çevre ve temiz enerji ile ilişkili reklamlarında beyaz renk temizliği ve safığı imleyen olarak kullanılmıştır. Skoda reklamlarında geniş bir renk yelpazesi görülmektedir. Enerji, dinamizm ve heyecanı temsil eden, dikkat çekici olan kırmızı (Kasım, 2005: 98) işlevselliğin ön planda olduğu Skoda reklamlarında daha çok kullanılmıştır. Yeni çıkan modellerin tanıtımında ise, gençliği ve büyümeyi temsil eden yeşil rengi (Kasım, 2005: 104) daha fazla sergilenmiştir. Böylece yeni çıkan ürünün 'yeniliği' rengiyle birlikte pekiştirilmiş olmaktadır. Özellikle genç hedef kitleye yönelik reklamlarda hareket ve enerjiyi temsil eden turuncu ve açık yeşil renkleri kullanılmıştır. Toplumsal anlamda refah ve mutluluğu simgeleyen, varlık ve konforla ilişkilendirilen (Kasım, 2005: 108) kahverenginin kullanıldığı Skoda reklamlarında mutluluğun birlikte verildiği, aracın üretilmesiyle, yenilenmesiyle yaşanan mutluluğun tüketiciye yansıtılması görülmektedir. Sadece reklamlarda kullanılan renklerde bile görülen anlatıların farklıı̆ı, Audi marka otomobili tanrısallaştırarak aristokrat sınıfının elde edebileceği değerde gösterdiği, Skoda marka otomobilin ise orta sınıf gençlere ve ailelere yönelik olduğu anlaşılmaktadır.

Tablo 1. Reklamlardaki Fiziksel Birimler

\begin{tabular}{|c|c|c|c|c|c|c|}
\hline Reklam & Süre (SN) & Renk & Sürücü & Fiyat & $\begin{array}{l}\text { Teknik Özellik } \\
\text { Anlatımı }\end{array}$ & $\begin{array}{l}\text { Arabanın Reklamda } \\
\text { Görünmesi }\end{array}$ \\
\hline $\mathrm{A} 1$ & 33 & & & & & \\
\hline A2 & 61 & Siyah & Kadın & & & + \\
\hline A3 & 61 & Beyaz & & & & + \\
\hline A4 & 49 & Gümüș & Erkek & & & + \\
\hline A5 & 25 & & & & & \\
\hline A6 & 32 & Gümüș & & & & + \\
\hline A7 & 41 & Gümüș & & & & + \\
\hline A8 & 32 & Siyah & Erkek & & & + \\
\hline A9 & 40 & $\begin{array}{l}\text { Kırmızı Beyaz } \\
\text { Gümüș }\end{array}$ & Kadın Erkek & & & + \\
\hline A10 & 41 & Beyaz & Kadın & & & + \\
\hline A11 & 31 & Beyaz & & & & + \\
\hline A12 & 60 & Siyah & & & & + \\
\hline $\mathrm{A} 13$ & 30 & Siyah & Kadın & & & + \\
\hline A14 & 60 & Siyah & Kadın & & & + \\
\hline A15 & 60 & Siyah & & & & + \\
\hline A16 & 32 & Gümüș & Erkek & & & + \\
\hline A17 & 30 & Gümüș & Erkek & & & + \\
\hline
\end{tabular}




\begin{tabular}{|c|c|c|c|c|c|c|}
\hline A18 & 31 & Gümüș & Kadın & & & + \\
\hline A19 & 32 & Gümüș & Erkek & & & + \\
\hline A20 & 51 & Siyah & & & & + \\
\hline S1 & 86 & Gümüș & Kadın & & & + \\
\hline S2 & 51 & Gümüș & & & & + \\
\hline S3 & 30 & Gümüș & & + & & + \\
\hline S4 & 30 & Beyaz & & + & + & + \\
\hline S5 & 31 & Kırmııı Gümüș & & & + & + \\
\hline S6 & 32 & Her renk & & & & + \\
\hline S7 & 35 & Kırmızı & & + & + & + \\
\hline S8 & 60 & Yeșil & & & & + \\
\hline S9 & 30 & Turuncu & & & & + \\
\hline S10 & 63 & Kum kahve & & & & + \\
\hline S11 & 29 & Kırmızı & & & + & + \\
\hline $\mathrm{S} 12$ & 30 & Gümüș & & & & + \\
\hline $\mathrm{S} 13$ & 46 & Gümüș & Erkek & & + & + \\
\hline S14 & 30 & Turuncu & Erkek Kadın & & + & + \\
\hline S15 & 31 & Gümüș & Erkek & & & + \\
\hline S16 & 31 & Kırmızı Mavi & Erkek & & & + \\
\hline S17 & 47 & & & & & \\
\hline S18 & 30 & Beyaz & Erkek & & & + \\
\hline S19 & 30 & Beyaz & Erkek & + & & + \\
\hline $\mathrm{S} 20$ & 57 & Yeșil & Erkek & & + & + \\
\hline
\end{tabular}

Audi 1 ve Audi 5, Skoda 17 reklamlarında otomobil hiç gösterilmemiştir. Söz konusu Audi reklamlarında otomobilin değeri simgelerle anlatıırken, Skoda reklamında ise bir toplantıda ürünün daha iyi hale getirilmesi için yapılabilecekler sorulmaktadır. Diğer bütün reklamlarda otomobiller reklam içinde gösterilmektedir.

Audi reklamlarında sürücüler daha çok kadın olarak gösterilmişlerdir. Audi reklamlarında 8 kadın, 6 erkek sürücü gösterilirken, 9 reklamda araç sürücüsü görünmemektedir. Audi reklamlarındaki sürücüler reklam metinlerinde ya tek olarak ya da yanlarında başka bir kişi (eş ya da çocuk) ile verilmiştir. Aile kurgusu yapılmamıştır. Skoda reklamlarında ise sürücülerin çoğu erkektir. Skoda reklamlarında 7 erkek sürücü, 1 kadın sürücü ve 13 reklam sürücüsüz olarak görünmektedir. Skoda reklamlarında araç içinde erkek sürücü ile birlikte diğer aile üyeleri de yer almaktadır. Bu bağlamda Audi otomobilin, farklılığa, özgürlüğe, bireysel yaşanan sürüş deneyimine ve tekil yaşanan hazlara vurgu yaptığı, Skoda otomobilin ise ailesel değerleri ve mutlu aile tablosu sunan bir yaşam tarzını ön plana çıkardığı, teknik özellikler ve fiyat belirterek rasyonel seçim yapma hazzına seslendiği değerlendirilmektedir. Bununla birlikte Skoda markasının da sürüş deneyimine yönelik reklamlar yapmaya başladığı görülmektedir. 


\subsection{Otomobili Fetiș Nesnesi Olarak Gösteren Reklamlar}

Audi marka otomobil reklamlarında otomobilin değerinin yüceltildiği, arzu ve fetiş nesnesi olarak sunulduğu, efsaneleştirildiği görülmüştür. Dokunulmaz olan, onun için hazırlık yapılan otomobil tüketiciyi yönlendirmekte ve yönetmektedir. Skoda reklamlarında, otomobil fetiş nesnesi olarak gösterilmemiş, genellikle arzulanan nesne yerine rasyonel sebeplerden tercih edilen tüketim ürünü olarak konumlandırılmıştır.

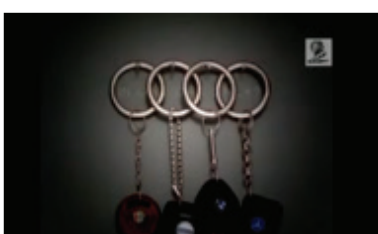

Reklam No. Audi 1

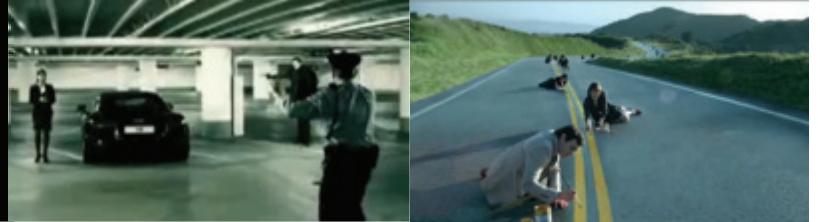

Reklam No. Audi 2
Reklam No. Audi 19

Sadece simgesel nesnelerle kurgulanmış olan Audi $1^{5}$ reklamında, Audi markası diğer otomobil markalarının sunduğu, tasarım, konfor, güvenlik ve sportif olma özelliklerinin hepsini taşıdığını belirtmektedir. Reklamda sadece simgelerin gösterilmesi, otomobilin gösterilmemesi tüketim kültüründe bahsedilen gerçekle bağlantının kopmasına ve dolayısıyla ürün-kullanım değeri bağlantısının da ayrışmasına işaret etmektedir. Audi marka otomobilin simgesel değeri, anahtar simgelerin gösterilmesiyle yüceltilmekte ve rakip ürün simgeleri küçük düşürülmektedir. Öte yandan reklamda gösterilen bir otomobil yoktur, hayal gücüne seslenen reklamla otomobil bir anlama sahip olmakta ve kendisini var etmektedir (Williamson, 2001: 35). Audi $2^{6}$ reklamında, otomobilin hem cinsiyet hem de birey anlamında kadından bile daha değerli olduğu gösterilmekte ve otomobil bir fetiş nesnesi haline getirilmektedir. Arzulanan ve vazgeçilemeyen, "klasik" olduğu vurgulanan otomobil aynı zamanda siyah olmasıyla asaleti de temsil etmektedir. Otomobilin fetiş nesnesi olarak gösterildiği reklamlardan bir diğeri olan Audi $19^{7}$ reklamında yolları araba için hazırlayanların takım elbiseli kadınlar ve erkekler olmaları da, arabaya tapan ancak arabaya sahip olabilecek üst sınıf gruplarına işaret ederek sınıf ayrımını pekiştirmektedir.

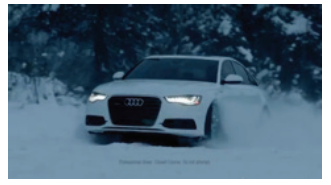

Reklam No. Audi 3

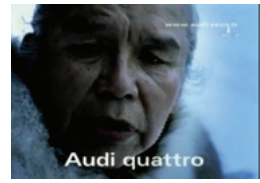

Reklam No. Audi 5

5 Audi 1 reklamında, sırasıyla diğer marka ürünlerin anahtarları yan yana konularak, tasarım, konfor, güvenlik ve sportif olma özelliklerinin bir arada bulunup bulunamayacağı sorulmaktadır. Sorunun cevabının verilmesi yerine görüntünün anahtarların baş kısmına odaklanması ve Audi logosuna dönüşmesi ile cevabın çağrışımla bulunması sağlanmaktadır. http://www.youtube.com/watch?v=pe4GEqmIVVg (19.09.2014).

6 Audi 2 reklamında bir otoparka gelen siyah Audi marka otomobilin görüntüsünün yanında elinde silah olan güvenlik görevlisinin birini takip ettiği görülmektedir. Polisiye film kurgusuyla verilen reklamda, otomobilden inen kadın, takip edilen kişi ve güvenlik görevlisi yan yana gelmektedirler. Takip edilen ve suçlu olarak konumlandırılan birey ve güvenlik görevlisi birbirlerine silah çekmekte, ardından suçlu olarak nitelendirilen kişi silahını önce kadına sonra otomobile yönlendirerek güvenlik görevlisini silahını atması, aksi halde otomobili vuracağı yönünde tehdit etmektedir. Güvenlik görevlisinin silahını bırakması ile "already clasic" sloganı ekrana gelmektedir.http://www.youtube.com/watch?v=eUlyrA46O9A (26.09.2014).

7 Audi 19 reklamında, otomobil için yolların temizliği konu alınmaktadır. Yol çizgilerini boyayan, ellerinde süpürgeleriyle yolları süpüren takım elbiseli insanlar arabaya verdikleri önemi göstermektedirler. Yolların temizlenmesiyle yakın çekim gelen otomobil tanrısal bir görüntüyle ve yüksek verilen motor sesiyle kendini göstermektedir. http://www.youtube.com/watch?v=0LnpXAmtsal (26.09.2014). 
Audi $3^{8}$ reklamında otomobil hikâye anlatısı aracılığıyla efsaneleştirilmektedir. Çekicinin sözleriyle arzu nesnesi haline gelen, farların göz olarak tasvir edilmesiyle insan biçimleştirilen otomobil, asla yakalanamayan (avlanamayan) bir efsane olmaktadır. Böylece tüketicilerine onu avladıklarında yani ona sahip olduklarında yaşayacakları hazzı vermeye çalışmaktadır. Audi5 ${ }^{9}$ reklamında marka adının, yırtıcı ve güçlü olan hayvanların peşi sıra söylenmesi hem otomobilin yırtıcı bir hayvana benzetildiği vurgusunu yapmakta hem de bir önceki reklama gönderme yaparak yakalanması kolay olmayan efsaneye işaret etmektedir. Otomobilin efsane olması aynı zamanda geçmişten gelerek unutulmaz olduğunu ve gelecekte de unutulmayacağını, otomobile de sahip olanların geçtikleri yerde iz bırakacakları çağrışımı yapmaktadır. Skoda reklamlarında otomobile efsane olma niteliği yüklendiği görülmemiştir.

\subsection{Teknoloji ve Güc Vurgusu Olan Reklamlar}

Otomobilin güçlü olması vurgusu ve tüketiciye bu gücün aktarılması Audi reklamlarında daha çok görülen bir unsur olarak karşımıza çıkmaktadır. Skoda reklamlarına bakıldığında hazzın yaşatılması yerine işlevsellik ve yenilik ön plana çıkmaktadır.

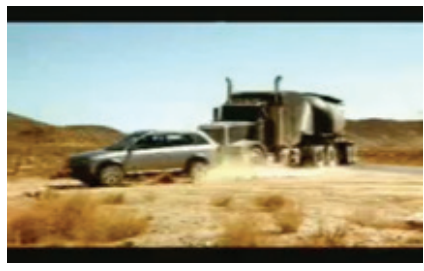

Reklam No. Audi 4

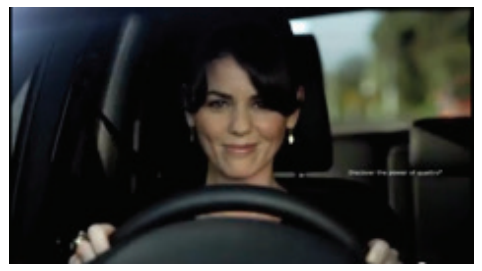

Reklam No. Audi 13

Gücün yüceltilmesi ve hızın gösterilmesi hem "harekete geçme" (Aygün Cengiz, 2009: 97) anlamıyla hızın fetişleştirilmesini sağlamakta hem de bireyin güç hazzı yaşamasını sağlayarak sembolik olarak güçlü olduğu duygusunu yaşamasına gönderme yapmaktadır. Bu duygu Audi $4^{10}$ reklamında dikiz aynasından gülümseyerek bakan erkeğin yüz ifadesinden de anlaşılmaktadır. Reklamın çekildiği mekânın, çöl ortamı olması otomobilin zorlu koşullardaki mücadele yeteneğine gönderme yaparak dayanıklılığı ve performansının yüksek olduğu belirtilmektedir. Hızla birleştirildiğinde, Audi markasının diğer markalardan güç, dayanıklılık ve performans açısından diğer markalardan önde olduğuna gönderme yapmaktadır. Gücü vurgulamasıyla ön plana çıkan bir diğer reklamda (Audi $13^{11}$ ) otomobilin kullanım kolaylığı aşama aşama gösterilerek, "kadınların bile rahatıkla kullanabileceği” miti desteklenmektedir. Ardından toplumsal olarak ikincil planda

8 Karlı ve dağlık bir bölgede çekici sahibi olarak hizmet veren bir adamın anlatılarının hikâyeleştirilmesi şeklinde verilen Audi 3 reklamında, önce çekicinin çektiği diğer araçlar gösterilmekte ardından da araçları çeken kişi bir otomobili asla yakalayamadığını, ona hiç yaklaşamadığını, (Audi'nin farları gösterilerek) o gözleri asla unutamadığını belirtmektedir. Karda iz süren avcı gibi gösterilen çekici yanından hızla geçen Audi marka otomobili görüp çığlık atmaktadır. http://www.youtube.com/watch?v=iwKwwqZLrsk (19.09.2014).

9 Audi 5 reklamında, otomobil hiç gösterilmemiştir. Torununa kardaki ayak izlerinden hayvanların anlaşımasını anlatan yaşı ı adam, kurt ve ayı örneklerini verdikten sonra Audi marka otomobilin modelini söylemektedir. http:// www.youtube.com/watch?v=20eCHfU1k84 (19.09.2014).

10 Bir film gibi kurgulanan Audi 4 reklamında, Audi marka otomobil bir tır tarafından takip ediliyor ve yoldan çıkarılıyor görünmektedir. Reklamın sonunda, otomobilin tır'ı çektiği anlaşıımakta ve 4 çeker V8 silindir hacminde olan motor özelliği ile güç vurgulanmaktadır. http://www.youtube.com/watch?v=xGZjO2XMTaQ (18.09.2014).

11 Audi 13 reklamında, öncelikle kadın sürücünün arabaya binişi aşama aşama gösterilmektedir. Burada aracın kadın tarafından da kolayca kullanılabiliyor olmasına işaret edilmektedir. Araçta bulunan ve kadını rahatsız eden bir sinek bulunmaktadır ve kadın fren yaparak sineğin cama yapışarak ölmesine neden olmaktadır. http:// www.youtube.com/watch?v=KrF9dxoYb_4 (19.09.2014). 
ve güçsüz gibi kalıp yargılarla nitelendirilen kadının bu rolün dışına çıkarak gücü hissetmesine, kendisini rahatsız edenleri ezip öldürebilecek kadar güçlü olmasına gönderme yapılmakta, "çalışan" kadının güçten aldığı haz yine yüz ifadesiyle de anlaşılmaktadır.

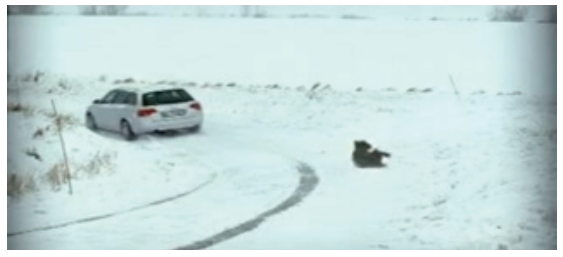

Reklam No. Audi 6

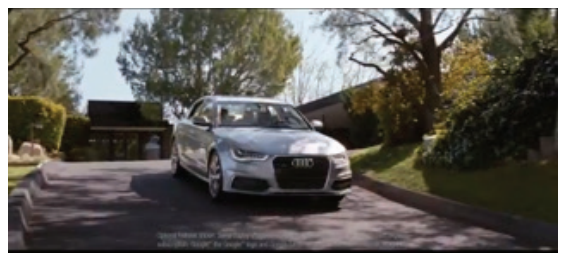

Reklam No. Audi 18

Audi marka otomobil reklamlarında gelişmiş teknoloji vurgusu çeşitli şekillerde verilmektedir. Bazen yol tutuşu, bazen motor gücü gibi tek bir özelliği hedef alırken bazen de otomobilin tamamı gelişmiş teknoloji ürünü olarak sunulmaktadır. Örneğin Audi $6^{12}$ reklamında yol tutuşu öncelenmiştir. Bu reklamda yolun dışına savrulan köpeğe doğanın bir unsuru olarak baktığımızda, otomobil hem kar gibi zorlu koşullar yaratan doğaya karşı koyabilmekte hem de köpek gibi doğanın diğer unsurlarından üstün olmaktadır. Söz konusu köpek rakip firma otomobilleri olarak algılandığında ise Audi marka otomobil, yoldan çıkan diğer otomobillerin aksine yol tutuşuyla güvenli yolculuğa olanak tanımaktadır. Köpek ayrıca sadakat ve dostluk yan anlamlarına gönderme yapmakta ve reklamda güvendiğiniz, sadık dostunuz olan arabanızdan vazgeçerek Audi alın denilmektedir. Bir diğer reklamda (Audi $18^{13}$ ), geliştirilmiş teknoloji ürünü olarak sunulan Audi marka otomobilin teknoloji tasviri, ürün özellikleri betimlenmeden yapılmaktadır. Teknolojinin ne olduğu üzerine bilgi verilmemekte, yaşattığı duygu üzerine yoğunlaşılmaktadır. Söz konusu reklamda çocuğun gözünden anlatılan ve uzay gemisi gibi tasvir edilen otomobil hem çocuk hayal gücü nedeniyle gerçeklikten uzaklaşmakta hem de bu dünyaya ait olmayan bir teknolojiye sahip olduğu belirtilmiş olmaktadır. "Birey, bir kapsülmüşçesine içine yerleştiği otomobilde kimse tarafından dokunulmayacağını bildiği için rahat etmektedir (Aygün Cengiz, 2009: 113)."

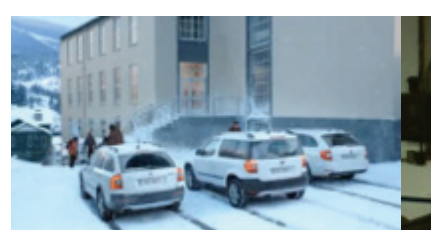

Reklam No. Skoda 18

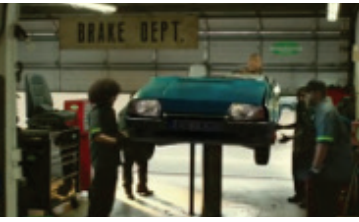

Reklam No. Skoda 14

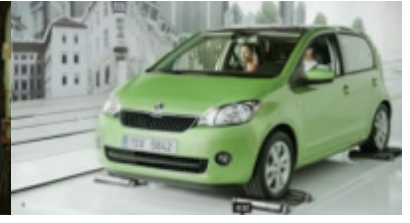

Reklam No. Skoda 20

Skoda marka otomobillerde gelişen teknoloji farklı şekillerde sunulmaktadır. Bazı reklamlarda ürün özellikleri işlevsel olarak sıralanmakta iken bazı reklamlarda da özellikler belirtilmeden kurgu içerisinde verilmektedir. Skoda $18^{14}$ reklamında, gelişen teknoloji getirdiği sürüş deneyimi ya da

12 Audi 6 reklamında, karlı bir yolda hareket halinde olan otomobili takip eden köpeğin, otomobilin rahatlıkla döndüğü virajı dönemeyerek yolun dışına savrulduğu görülmektedir. http://www.youtube.com/ watch?v=tWIOFeXLedM (18.09.2014).

13 Audi 18 reklamında çocuğun gözünden babası anlatılmaktadır. Çocuk babasının uzaylı olduğuna dair inancına kanıtlar göstermektedir. Son kanıtı ise uzay gemisine benzetilen Audi marka otomobile sahip olmasıdır. Söz konusu kanıt söylenirken otomobilin içi ve dışının özellikleri bir uzay gemisi ihtişamıyla gösterilmektedir. http://www.youtube.com/watch?v=kWAWS76aG3k (19.09.2014).

14 Skoda 18 reklamında yoğun kar yağışı nedeniyle okulların tatil olduğunu duyan çocuklar sevinmekte ancak sadece Skoda otomobil sahibi olan veliler çocuklarını okula götürebilmektedir. Kahvaltı masasında "mutlu aile 
duygularla değil, güvenle ilişkilendirilmektedir. Reklamda gösterilen aile kurgusuyla, otomobilin ailenizin güvenle seyahati için uygun teknolojik yeterliliğe sahip olduğu anlaşımaktadır. Skoda markası gerçekleştirdiği yenilikleri yaşadığı dönüşümü reklamlarına da yansıtmaktadır. Skoda $14^{15}$ reklamında tamir edilmesi için tamirciye bırakılan Skoda otomobil, tamamen değişmiş ve yeni bir model olarak karşımıza çıkmaktadır. Skoda markası ve otomobilleri, 1991 yılında Volkswagen Grubu tarafından satın alınmasının ardından bir değişim ve dönüşüm sürecine girmiş, yeni modeller üretilmiş ve farklı hedef kitlelerine yönelik tasarımlar yapılmaya başlanmıştır. Bu reklam da Skoda'nın yaşadığı dönüşüme gönderme yaparak sonucun hayranlık verici olduğu duygusunu yaratmaktadır. Bu dönüşümün ardından üretilen Citigo modeli yeni iletişim aracı olarak lanse edilmiştir. Hedef kitlesinin gençler olduğu değerlendirilen modelin reklamlarında nüktedan bir dil kullanılarak otomobilin özellikleri gençlerin ilgi alanları düşünülerek anlatılmıştır. Skoda $20^{16}$ reklamında da önlüğüyle bir bilim adamı olduğu değerlendirilen kişi otomobilin özelliklerini anlatmaktadır. Reklamdaki arka planın kurgu olması otomobilin "gerçek" olarak algılanmasına yol açmaktadır. Reklam uygulamalarında ürünler farklılaştııılarak bir ürüne kimlik verilebileceği (Williamson, 2001: 28) bağlamından yola çıktığımızda Citigo modeline genç iletişimci kimliği verilmiş ve Skoda'nın aile arabası modellerinden farklılaştırılmış olduğu söylenebilir.

\subsection{Kimlik ve Yașam Tarzını Önceleyen Reklamlar}

Tüketim kültüründe ürünler tüketicinin yerine geçerek onu gösterirler. "Biricik anlamı toplumda zaten var olan mitolojik öğelerden alan ürünler, öyle bir anlamlı hava geliştirirler ki, kendilerini satın alanlara bir şeyler anlatır ve onlarla ilişkileri içinde fiilen sıfatlaşırlar (Williamson, 2001: 46)." Böylece ürünü kullanan birey hem ürünle özdeşleşir hem de diğer insanlardan farklılaşır. Audi/Skoda kullanan birey kullanmayanlardan ayrıı. Bu durumun farkındalığıyla Audi reklamları, farklıı̆ğı belirginleştirmeye çalışmıştır.

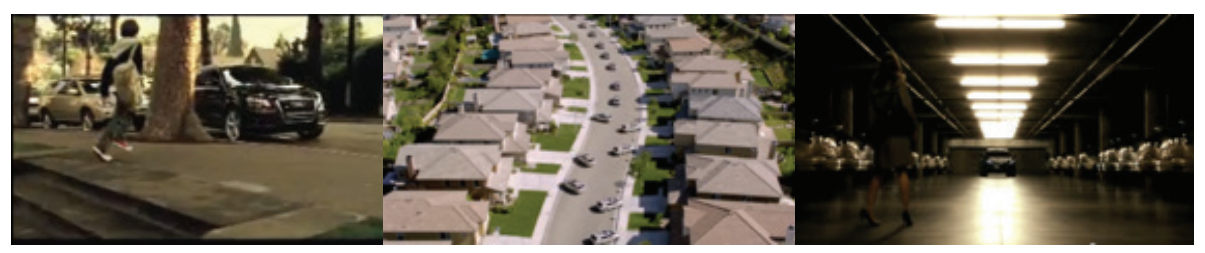

Reklam No. Audi 8

Reklam No. Audi 17

Reklam No. Audi 12

Audi $8^{17}$ reklamında, diğerlerinden önce öne çıkarak otomobile binen çocuk farklı olmanın hazzını yaşarken, kimliğin herkesi etkilediği ve Audi otomobilin karşıllaştırılamaz olduğu sloganıyla reklam

tablosu" ile başlayan reklam kurgusunda Skoda otomobilin yol tutuş özelliği sergilenirken, aile bireylerinin güvenle seyahat ettiği bir otomobil tasavvuru yapılmaktadır. http://www.youtube.com/watch?v=|JmMrU3Jf8E (18.09.2014).

15 http://www.youtube.com/watch?v=mz6u2Kym7eQ (24.01.2013).

16 Skoda'nın arkadaşlarınızla gerçek hayatta görüşmeniz için yeni iletişim aracı sloganıyla başlayan Skoda 20 reklamında, beyaz önlükle gösterilen ve otomobili kullanan kişi otomobilin özelliklerini anlatmaktadır. Otomobilin navigasyon aplikasyonu, telefon aplikasyonu, müzik aplikasyonu gibi özellikleri örneklerle anlatılmaktadır. http://www.youtube.com/watch?v=nvn9-esY9qg (24.01.2013).

17 Audi 8 reklamında, okul çıkışında velilerinin kendisini almasını bekleyen çocuklar dışarıya baktıklarında aynı renk ve biçimde arabalar görmektedir. Sadece bir çocuk kendisini siyah bir Audi marka otomobille almaya gelen velisinin otomobiline binmektedir. http://www.youtube.com/watch?v=BiVus5dIGMo (19.09.2014). 
sonlanmaktadır. Aynı şekilde farklılık kurgusuyla yapılmış Audi $17^{18}$ ve Audi $12^{19}$ reklamlarında da Audi marka otomobile sahip olmak ile farklılık ilişkilendirilmiştir. Söz konusu üç reklamda öncelikle, farklılık ve kimlik vurgusunun kadın ve çocuklar üzerinden yürütüldüğü görülmektedir. Bu durumun muhtemelen, kadın ve çocukların bulundukları ortamda daha çok farklılığa ihtiyaç duydukları anlayışından yapıldığı değerlendirilmektedir. Bu anlayışın doğru olup olmadığı tartışması bir kenara bırakıldığında, Audi reklamlarında genel olarak kadınların otomobil sahibi olduklarında farklı, kimlik sahibi, cazibeli vb olacakları, erkeklerin heyecan, tutku, güç ve hız gibi duyguları deneyimleyecekleri kurgusunun olduğu anlaşılmaktadır. Skoda reklamlarında bu kadar belirgin farklılık vurgusu tespit edilememiştir. Öte yandan özellikle Audi reklamlarında farklılığın yanı sıra yaşam tarzı vurgusunun da yer aldığı görünmektedir.

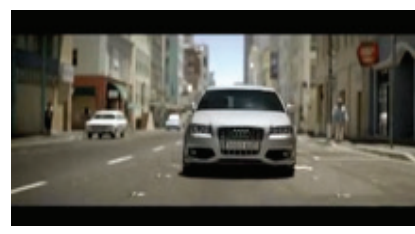

Reklam No. Audi 7

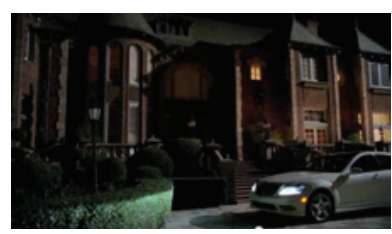

Reklam No. Audi 14

Otomobil ile kendi kimliğini yansıtan tüketicinin sanatçı ruhuna seslenen Audi $7^{20}$ reklamında, tüketici otomobili aldığında kendini sanatçı gibi hissedebilecektir. Otomobile sahip olan tüketici klasik müzikle bağlantılandırılan bir şekilde sosyal sermayesine yatırım yapmış olacaktır. Ayrıca, hassas kullanım özellikleriyle, yumuşak sürüş keyfini deneyimleyecektir. Öte yandan Skoda reklamlarına bakıldığında, yine kadehlerle müzik yapılan bir reklam (Skoda $2^{21}$ ) olduğu görünmektedir. Ancak söz konusu reklamda bir müzisyen müzik yapmaktadır ve otomobil sanatçı gibi konuşlandırılmamıştır.

Audi reklamlarında kendi rakiplerini ve onların çağrıştırdıklarını göstermekten kaçınmamaktadır. Örneğin Audi 1422reklamında yeni bir yaşam tarzı olarak sunulan Audi marka otomobilden önce Mercedes marka otomobil sahibi olan insanların gösterişçi ve lüks tüketimi gösterilmektedir. Bu

18 Audi 17 reklamında evden okula doğru annesinin arabasıyla yola çıkan çocuğun şehirdeki izlenimleri gösterilmektedir. Aynı evlerde oturan, aynı tip arabalara binen, aynı şekilde hareket eden ve spor yapan şehir insanlarından sonra, okul çantalarına kadar aynı olan öğrenciler gösterilmektedir. Farklı otomobile binen ve çanta rengi diğerlerinden farklılaşan çocuk imgesinin gösterildiği reklam Oscar Wilde'in 'kendin ol, başka herkes alınmış" ve "yeni Audinin farkı" sözleriyle sonlanmaktadır. http://www.youtube.com/watch?v=soJs3ZUYtLI (19.09.2014).

19 Audi 12 reklamında otoparkta birbirine benzeyen arabalar içerisinde kendi arabasını bulamayan ve bu nedenle gerginlik yaşayan bir kadın görünmektedir. Kadın ne yapacağını bilemez bir haldeyken, garajdan Audi marka otomobille başka bir kadın çıkmakta ve şehrin renkli sokaklarında otomobilini kullanmaktadır. http://www. youtube.com/watch?NR=1\&v=PUw1QI-Q738 (19.09.2014).

20 Audi 7 reklamında, şehirde yan yana dizilmiş şişelerin bulunduğu bir yolda Audi marka otomobil, şişelerin yanından geçerek ve tekerine bağlanmış olan baget gibi bir nesneyle şişelerin yanından geçtiğinde farklı notalar çalarak müzik yapması gösterilmektedir. Burada otomobil şişeleri devirmeyecek ve kırmayacak kadar hassas ve aynı zamanda müzik üreten bir sanatçı olarak konumlandırılmaktadır. http://www.youtube.com/ watch?NR=1\&v=SYunqmkK8lw (18.09.2014).

$21 \mathrm{http} / / / w w w . y o u t u b e . c o m / w a t c h ? v=J 6 k X R O c R D 38$ (24.01.2013).

22 "İyi geceler" ve "günaydın" sözleriyle anlatılan Audi 14 reklamında, Mercedes marka otomobilin Audi üreticilerine göre çağrıştırdığı, lüks ürünler, eski kafalı, resmi nesnelere iyi geceler denilmekte ve ürünlerin içinde bulunduğu ev sakinleriyle birlikte uyumaktadır. Uykunun gösterildiği son sahnede Mercedes marka otomobil evin önünde uyumaktadır. Günaydın ile başlayan kısımda ise Audi marka otomobil gösterilerek, eliminasyon, yükselme, eşsiz ilham gibi kavramlara günaydın denilmekte ve lüks kavramının artık değiştiği ifade edilmektedir. http://www.youtube.com/watch?v=oVSq2b35L4k (26.09.2014). 
reklamda lüks, gösterişçi tüketimin olduğu yaşam tarzı küçük düşürülürken, ayrıcalığın yaşandığı yeni bir yaşam tarzı tüketicilere seslenmektedir.

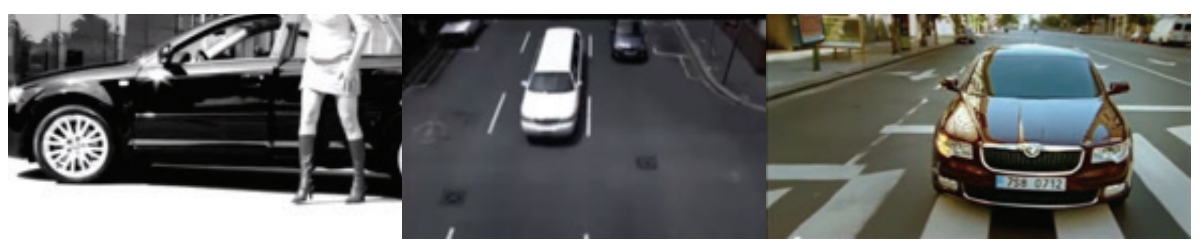

Reklam No. Audi 20

Reklam No. Skoda 15

Reklam No. Skoda 11

Audi $20^{23}$ reklamında ise, ideal kadının yaşam tarzı resmedilmektedir. (Senin) ortalaman aile reisi kadın (anaerkil) değil ve ortalaman hatchback değil sözleriyle devam eden reklamda, kadının yeni tasarım hatchback otomobiliyle standartların üzerinde bir yaşam tarzına sahip olduğu çağrışımı yapılmaktadır. Söz konusu yaşam tarzını sağlayan şey ise alışık olmadığı, başka bir şey olduğu söylenen Audi marka otomobil olmaktadır.

Skoda marka otomobilin tasvir ettiği yaşam tarzı daha rasyonel ve aile gibi sosyal unsurlara değer verir şekilde sunulmaktadır. Skoda reklamlarında otomobil kullanıcılarının yanında sevdikleri yer almaktadır. Skoda $15^{24}$ numaralı reklamda da markanın farkı bu şekilde belirtilmekte ve aileye önem verilen yaşam tarzı ön plana çıkarılmaktadır. Bu reklamda diğer markaların (Audi, BMW, Mercedes vb.) temsil ettiği ya da simgelendiği güç, hayranlık, farklılık gibi unsurlar dışlanarak onların temsil ettiği yaşam tarzı da dışlanmaktadır. Ailenin ve sevginin önemi vurgulanmakta, diğer simgesel değerlerin yerine aile bağları konulmaktadır. Bu bağlamda Skoda'nın kendini bir aile otomobili olarak konumlandırdığı söylenebilmektedir. Böyle bir konumlandırma ile bireysel değerlere değil, kolektif değerlere seslenmektedir. Bununla birlikte Skoda $11^{25}$ reklamında görüldüğü üzere Skoda markasının simgesel değerlere geçiş yaptığı görülmektedir. Otomobilin işlevsel özelliklerinin klasik müzik eşliğinde verilmesi aristokrasiye ve üst sınıfa gönderme yapmaktadır. Aynı zamanda tüketicinin zengin görünme hayaline gönderme yapılan reklamda, "zengin gösterir" söylemi, tüketicilerin aldıkları ürünle sınıf atlama hayallerinin Skoda marka otomobille gerçekleştirileceği anlaşılmaktadır. Audi markasının temsil ettiği statü grubuna seslenmeyen, onları taklit eden tüketicilere seslendiği değerlendirilen reklam filmine göre, otomobili alan tüketici sınıf atladığı yanılsamasını yaşayacaktır.

23 Audi 20 reklamında, otomobilinin içerisinde makyaj yapan, kuru temizlemeye giden, ardından çocuğunu arabaya bindiren kadın, çekici, cazibeli, enerjik olarak betimlenirken arabanın parçaları gösterilerek betimlemelere araç da dâhil edilmektedir. http://www.youtube.com/watch?v=R38Gc8pvdVo (19.09.2014).

24 Skoda 15 reklamında, iş yerinden çıkan üst düzey görünümlü erkek, otomobilinde seyahat edilirken başarı nedir sorusu sorulmaktadır. Başarı 'cüzdan (para) mıdır' denirken, otomobilin camından, yanında genç ve güzel bir kadın bulunan zengin olduğu anlaşılan yaşlı bir adam görülmektedir. 'Güce sahip olmak mıdır' ifadesi kullanılırken şehrin yüksek binaları gösterilmektedir. 'Ünlü olmak mıdır' sorusu sorulurken yanda limuzini içerisinde ünlü olduğu tahmin edilen bir kadın gösterilmektedir. 'Size hayranlık duyulması mıdır' denirken bir sanatçının afişi binaya asılmaktadır. Son olarak başarı sizin için gerçekten önemli olan şeyleri tanımlamak mıdır denirken eve gelen sürücünün otomobiline çocuklar binmekte ve kendisine neşeyle sarılmaktadırlar. http:// www.youtube.com/watch?v=eUlyrA46O9A (24.01.2013).

25 Skoda marka otomobilin özelliklerinin klasik müzik eşliğinde sadece gösterildiği Skoda 11 reklamı "ne düşündüğünüzü biliyoruz" ve "değerli gösterir" sloganlarıyla tamamlanmaktadır. http://www.youtube.com/ watch?v=_Ejpl-SeQ1I (18.09.2014). 


\section{4. Çevre Vurgusu Olan Reklamlar}

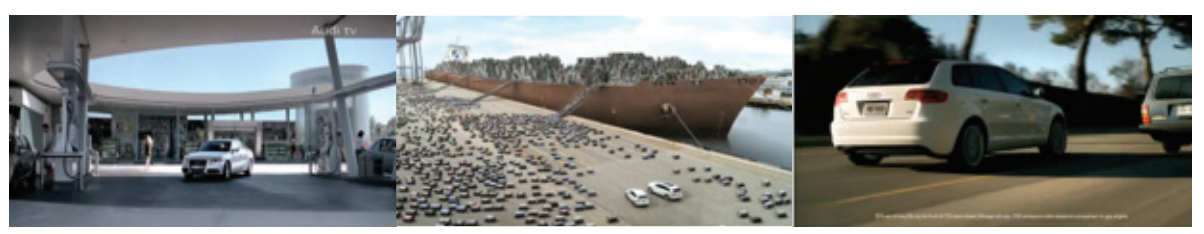

Reklam No. Audi 9

Reklam No. Audi 10

Reklam No. Audi 11

Audi markası otomobillerinin çevreye duyarlı olduğunu ve daha az yakıt tükettiğini farklı şekillerde göstermektedir. Örneğin Audi $9^{26}$ reklamında insanların otomobillerine az yakıt aldıkları bu nedenle yakıt deposunun nerede olduğunu hatırlayamadıkları mesajı verilirken Audi marka otomobillerin yakıt tüketimi hakkında gerçek bir bilgi verilmemektedir. Audi markasının altı silindirli ve daha fazla silindir hacmindeki otomobillerin yakıt tüketiminin fazla olduğu yönündeki olumsuz değerlendirmelere reklamla cevap verdiği değerlendirilmektedir. Ayrıca yakıt tüketiminde etkinliğin standart olduğu söylenen reklam filminde verilen örneklerden, Audi markasının farklı gruplara hitap eden çeşitlerinin bulunduğu ancak farklı grupların da üst sınıf üyeleri olduğu anlaşılmaktadır. Yine herhangi bir şekilde yakıt tüketimi verilerinin belirtilmediği ve simgesel olarak anlatılan Audi $10^{27}$ reklamında da Audi marka otomobillerin daha az yakıt tüketimiyle çevreye duyarlı olduğu açıklanmaktadır.

Çevreye duyarlıığın öncelendiği bir diğer reklam olan Audi $11^{28}$ reklamında, hem duyarlılık hem de diğerlerinden üstün olma hali vurgulanmakta, aracın yakıt tüketimi ile ilgili bilgi verilmemekte, modelin karbondioksit salınım miktarı belirtilmektedir. Temiz dizel ve daha temiz bir dünyaya doğru sloganıyla verilen reklamda, endüstri ürünlerinin ve otomobillerin çevreye verdiği zararların olmadığı izlenimi yaratılmaya çalışılmaktadır. Her üç reklamda da beyaz renk otomobil kullanılmış olmasıyla saflık, dürüstlük, temizlik yan anlamlarıyla pekiştirilmeye çalışılmıştır. Diğer taraftan özellikle Audi marka otomobil reklamlarında çevreyle mücadele eden, çöl ortamında, karlı yollarda doğaya karşı üstün olduğunu savunan otomobil imgesi de verilmektedir. Otomobil doğadan uzaklaşıp uygarlığa geri dönebilmemizin aracıdır (Williamson, 2001: 115) ve söz konusu reklamlar mücadele ederken aynı zamanda nasıl duyarı olunabileceği çelişkisini içinde barındırmaktadır. Bununla birlikte Skoda marka otomobil reklamlarında çevre vurgusu olan reklam olmasa da rasyonel tüketiciye seslenen reklamlarında yakıt tüketim açıklaması verilmiştir.

\subsection{Duygulara Seslenen Reklamlar}

Audi marka otomobil reklamlarında çağrışımları yapılan duyguların yüksek seviyede yaşanması,

26 Audi 9 reklamında bir toplantı odasında bulunan iş adamı, golf oynayan biri, arabada iki genç, çocuğuyla benzin istasyonuna gelen anne gibi faklı gruplarda olan insanların otomobillerine az yakıt aldıkları bu nedenle yakıt deposunun nerede olduğunu hatırlayamadıkları görülmektedir. http://www.youtube.com/ watch?NR=1\&v=G59Ycd4YfIE (19.09.2014).

27 Audi 10 reklamında şehrin içinden limana kadar giden yakıt varillerinin limana gittiği ve Audi marka otomobillerin onları izlediği görülmektedir. http://www.youtube.com/watch?NR=1\&v=xBKDLJUevrY (19.09.2014).

28 Audi 11 reklamında, insanların çevreyi korumak adına yaptıkları şeyler alay bir dilde anlatılmaktadır. Toplu taşıma aracına binerek sıkışıklık yaşayan, bisikletle yağmur altında çamura bulanarak giden, scooterla insanlar arasından geçemeyen erkeklerin ardından, bitkisel yakıtla yokuşu tırmanamayan bir araç gösterilmektedir. Bazıları kendi üstlerine düşeni yapmaya çalışıyor ama biri sizin için yaptı denilerek gösterilen Audi otomobil, çevreye duyarlı olmasının yanında, yağmurda çamurda gösterilenlerin aksine güneşli bir manzarada, bitkisel yakıtla çalışan otomobili geçmektedir. http://www.youtube.com/watch?NR=1\&v=aYoq4gIQV8s (19.09.2014). 
abartılması istenmektedir. Gündelik yaşam pratiklerinde normal koşullarda yaşanması beklenen aşk, sevgi, huzur gibi duyguların yerine, güç, heyecan, şüphe, gerginlik gibi duygular verilmektedir. Böylece tüketicilerin günlük yaşamın dışına çıkabilecekleri, farklı duyguları yaşayabilecekleri bir ortam yanılsaması yaratımaktadır. Bu yanılsamanın yaratıldığı Audi $15^{29}$ reklamında "her dakika abartın" (heighten every moment) sloganıyla verilen otomobil, abartılı duyguların yaşanmasını sağlayacak bir nesne olarak sunulmaktadır. Skoda marka otomobillerin reklamlarında ise yaşanan duygular daha çok aile ile yaşanan mutluluk, sevgi, özgürlük, huzur gibi duygular olarak gösterilmektedir.

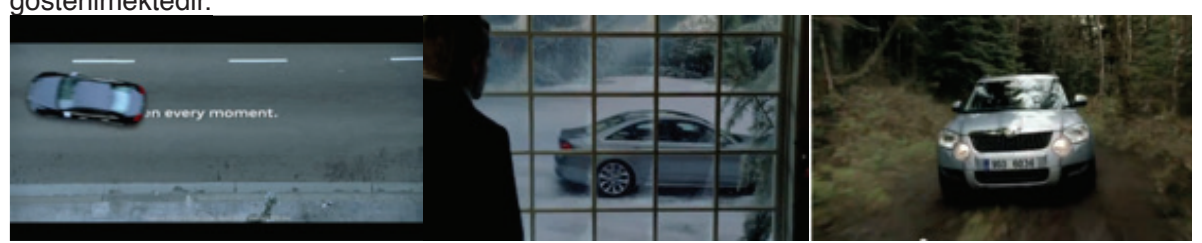

Reklam No. Audi 15
Reklam No. Skoda 12

Audi marka otomobillerin yaşattığı farklı duygular, aynı zamanda yeniliğe ve gelenekten kurtuluşa da kapı açmaktadır. Yeniliğe vurgu yapılan Audi $16^{30}$ reklamında özel günlerde aile ile birlikte olma gibi geleneksel değerlerin yerini alan otomobil ile çıkılacak yolculuğun yaşatacağı heyecan verici deneyim sergilenmektedir. "Anne" ve "Baba" heyecanı yaşamak için otomobili kaçırmakta, izin istememektedirler. Geleneksel değerlere önem verdiği izlenimi yaratılmaya çalışılan Skoda reklamlarında geleneklerden kopuş ve yaşanacak aykırı duygular teması işlenmemektedir. Geleneksel değerler ve duyguları dışında verilen aykırı sayılabilecek duygu maceralı sürüş deneyiminin verdiği heyecandır. Örneğin Skoda $12^{31}$ reklamında, vahşi şeyler için hazırlandı sloganı ile aracın vahşi doğasının ilgi çektiği izlenimi verilmiştir. Otomobilde seyahat eden ailenin gösterildiği reklamda otomobilin takip edilecek kadar çekici olduğu, doğanın zorlu koşullarında aileyle seyahat edilecek kadar güvenilir ve konforlu olduğu mesajının verildiği görülmektedir. Diğer taraftan reklamda verilen modelin, bir SUV olduğu (Sport utility vehicle//spor amaçlı taşıt) görülmektedir. Reklamın muhtemelen, SUV tipi jiplerin küçük olduğu, gerçek jipin yerini tutamayacağı, zorlu koşullarda 4 çeker olarak performans gösteremeyeceği gibi basmakalıplara yanıt verdiği değerlendirilmektedir.

29 Audi 15 reklamında, arabasının içinde bekleyen bir erkek görülmektedir. Bir bankanın yanında bekleyen kişi, çevredeki banka görevlisi, para nakliye aracı gibi unsurların gösterilmesi ile bir soygun sahnesi gibi tasarlanan ortamda gösterilmekte ve gerginleşmektedir. Kişinin soygun anında arabasıyla kaçacağı an beklenirken arabaya elinde bir paketle bir kadın binmektedir. http://www.youtube.com/watch?v=wtFkqQbNajl (19.09.2014).

30 Audi 16 numaralı reklamda geleneksel Noel hazırlığı kurgusunda anne ve baba yanlarına gelecek çocukları için özenle hazırlık yapmaktadırlar. Audi otomobiliyle gelen ve eve giren çocuk seslendiğinde kimse cevap vermemekte, camdan baktığında ise anne ve babasının otomobilini alıp uzaklaştıklarını görmektedir. Yeni bir tatil geleneğine yol açın sloganıyla sonlanan reklamda yaşı anne ve babanın keyifle otomobil içindeki anları gösterilmektedir. http://www.youtube.com/watch?v=K7tiJHLXjj4 (24.01.2013).

31 Skoda 12 reklamında ormanda vahşi bir şey tarafından takip edildiği düşünülen Skoda otomobilin içindeki aile huzurlu bir şekilde yolculuk etmektedir. Takip eden ve ne olduğu gösterilmeyen, vahşi bir hayvan olduğunu izleyicide uyandıran şey, reklamın sonunda otomobilden inip kendisini fark eden ve şaka yapar şekilde gülümseyerek ona hırlayan küçük kız tarafından uzaklaştııılmaktadır. http://www.youtube.com/ watch? $=$ bNrE38ov8LY (18.09.2014). 


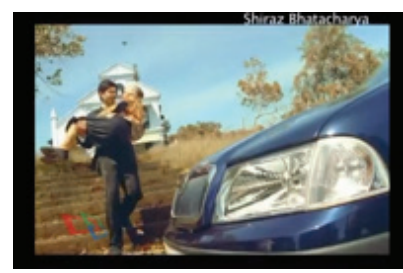

Reklam No. Skoda 16

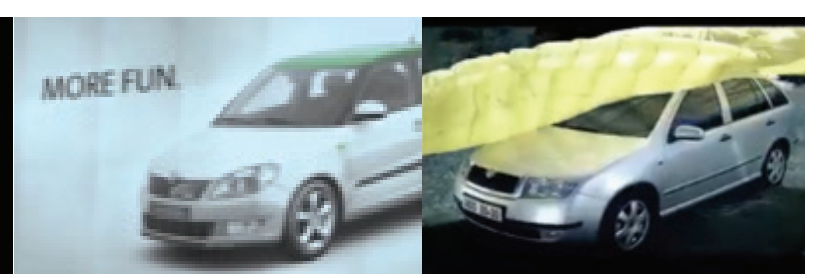

Reklam No. Skoda 6
Reklam No. Skoda 13

Skoda $16^{32}$ reklamında ise otomobil farklı bireylerin birbirlerini kucaklarında taşımalarının gösterimiyle bizi de kucaklayıp götürdüğü mesajını vermektedir. Söz konusu reklamda da olumlu, sevgi dolu duygulara seslenilmektedir. Reklamda ayrıca sevdiklerimizi emanet edebileceğimiz kadar güvendiğimiz bir otomobil çağrışımı bulunmaktadır.

Skoda marka otomobiller arasında yeni üretilen modellerin reklamlarında hedef kitlenin aileden farklılaştığı, eğlence macera, sürüş deneyimi gibi simgesel değerlere yönelim olduğu görülmektedir. Böylece Skoda markası, ürünün teknik özelliklerinin anlatıldığı işlevsel reklam anlayışının dışına çıkmış olmaktadır. Örneğin Skoda $6^{33}$ reklamında sadece renklerin gösterilmesi ile yüzeye yapılan vurgu ve eğlence teması, rasyonel tercih yapan tüketici yerine genç olan ya da genç hisseden tüketiciye seslenmektedir. Yine otomobil içinde macera deneyiminin verildiğiSkoda $19^{34}$ reklamında, şelalenin önünden geçilmesi ile zorlu koşullarla mücadele yeteneğinin, kaplan ile otomobilin hızının, uçan papağanlar ile özgürlük hissinin ve karşılarına çıkan fillerle gücün temsil edildiği değerlendirilmektedir. Ancak Skoda reklamlarındaki duygular Audi reklamlarındaki gibi aykırı duygular değildir. Yaşanılan duygular yine sevdiklerle (sevgili, aile vb) ortak yaşanan pozitif duygulardır. Birçok duyguyu bir arada veren Skoda $13^{35}$ reklamında ilk görünen aşktır. Skoda reklamlarında görülen işlevsellikle birlikte duygulara hitap eden bu reklamda yine sevgiyle gelen olumlu duygular yüceltilerek verilmiştir. Erkeğin arkasından merakla giden kadın, onun yaşadığı özgürlük hissine katılmakta ve onun için sevinmektedir. Yamaç paraşütü görüntülerinin yanında kadının otomobille gösterilmesi, otomobil sahibi olan kadınların yaşayacağı özgürlüğe işaret etmektedir.

32 Skoda 16 reklamında, babalarıyla oynayan çocuklar, sahilde iki sevgili, yaşlı annesinin yanında bir erkek ve ekinlerin arasında bir çift görünmektedir. Çiftlerin bulunduğu her ortamda farklı renklerde Skoda marka otomobiller görünmektedir. Aile içinde mutlu ve birbirlerini kucakta taşıyan olarak gösterilen bireylerin ardından reklam sevdiklerinizin taşınması için üretilmiş bir otomobile intiyacınız var sloganıyla sonlanmaktadır. http:// www.youtube.com/watch?v=JXDaFVYQ_TI (18.09.2014).

33 Bateri çalan bir gencin ve onu izleyen şehirdeki diğer insanların gösterildiği Skoda 6 reklamında, billboardlardaki, afişlerdeki Skoda otomobilleri her vuruşla birlikte renk değiştirmektedir. Daha çok renk daha çok eğlence sloganıyla üretilen reklamda, otomobilin 2112 renk varyasyonuna sahip olduğu belirtilmektedir. http://www.youtube.com/watch?NR=1\&v=HqPH4wwQ0BI (24.01.2013).

34 Skoda marka otomobillerin sürüş keyfini ön plana çıkardığı Skoda 19 reklamında, araç içerisindeki çift, şehir içinde seyahat ederlerken ormanla ilişkilendirilen unsurlar görmektedirler. Bir bina şelaleye dönüşmekte, önlerinden kaplan geçmekte, papağanlar onları takip etmekte ve en son karşılarına filler çıkmaktadır. Macera sloganı ile verilen reklam otomobilin fiyatının verilmesiyle sonlanmaktadır. http://www.youtube.com/ watch?v=LGySYGMLOuo (18.09.2014).

35 İki sevgilinin yaşadığı aşkın gösterildiği Skoda 13 reklamında, çift otomobiliyle yüksek bir yere gitmektedir ve erkek sürücü otomobilden inerek bisiklete binmektedir. Erkek bisikletiyle hızlanarak yamaç paraşütü yapmakta, kadın ise otomobil ile onu takip etmektedir. Sadece bisikleti gören ve erkeği göremediği için meraklanan kadın, erkeği görerek endişesinden kurtulmakta ve çift birbirine sarılmaktadır. Reklamda ayrıca otomobilin özellikleri, kullanımıyla ilişkilendirilerek verilmiştir. Bisikletin bagajdan çıkarılmasıyla geniş iç hacim, kadının erkeği takibi sırasında motor ve güvenlik özellikleri gösterilmiştir. http://www.youtube.com/watch?v=11YtTeVYDEo (18.09.2014). 


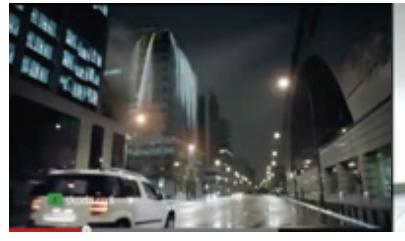

Reklam No. Skoda 19

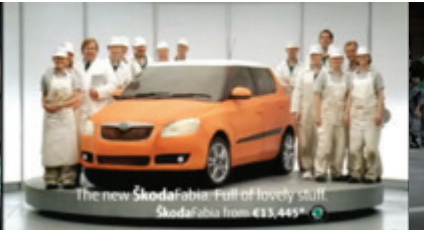

Reklam No. Skoda 9

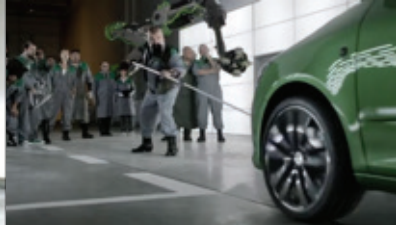

Reklam No. Skoda 8

Rasyonelin dışına çıkan Skoda reklamlarına bir başka örnek olarak üretim temalı olanlar gösterilebilir. Otomobilin üretim aşamalarını metaforlar aracıı̆̆ıyla anlatan reklamlarda farklı duygulara seslenilerek farklı çağrışımlar yapılmaktadır. Skoda $9^{36}$ reklamında otomobilin aşkla üretildiği mesajı pasta metaforuyla verilmektedir. Fantastik öğelerle gösterilen Skoda $8^{37}$ reklamında, her öğe otomobilin gücüne, turbo motoruna, performansına, ivmelenmesine, vahşi doğasına gönderme yapmaktadır. Son olarak Skoda $10^{38}$ reklamında heykel olarak üretilen otomobilin bir sanat eseri olarak kabul edildiği ya da üretimde kumun kullanılması temasının, otomobilin doğanın içinden çıktığı ve tüketiciyi, otomobilin mekanik üretim ürünü olduğu gerçeğinden uzaklaştırmaya çalışıldığı varsayılabilir. Sonuç olarak her üç reklamda da ürünün işlevselliği ile ilgili bilgi verilmediği, üretim aşamasının farklı duygular eşliğinde temsil edildiği, rasyonel tüketiciye seslenen tek unsurun otomobilin fiyatının verilmesi olduğu görülmektedir. Audi reklamlarında otomobil fiyatları ile ilgili bilgi verilmemesinin yanında üretime dair anlatılar (teknoloji ile üretildi, güç için üretildi vb) dışında vurgu yapılmadığı görülmektedir. Üretim temalı reklamlardan bir diğeri Skoda 1 'de ${ }^{39}$ düğün hazırlıklarının her aşamasında gösterilen otomobilin, insan biçimleştirilerek hazırlıklara yardım eder bir görüntüde verildiği görülmektedir. Her şeyin mükemmel olmasının arzulandığı düğün hazırlıklarının otomobil için de yapıldığı anlatısı, otomobilin bizim için özenle üretildiği izlenimi yaratmaktadır. Bunun yanı sıra yerelle ilişkilendirilen düğün geleneklerinin ve otomobilin teknik kontrolünün gösterilmesiyle yerelle moderni birleştirmiş ve hedef kitlesini genişletmiş olmaktadır.

36 Pasta olarak adlandırılan Skoda 9 reklamında, büyük bir mutfakta aşkla üretilen pasta şeklinde bir otomobil gösterilmektedir. Hamurun yapılışından, pişirilmesine, kremasından şekil verilmesine kadar her aşamanın gösterildiği reklam filmi "full of lovely stuff" sloganıyla verilmekte ve arabanın şeker gibi olduğu çağrışımı yapılmaktadır. http://www.youtube.com/watch?v=NwBE1l6QexU (18.09.2014).

37 Skoda 8 reklamında, ürünün fantastik öğelerle üretildiği izlenimini vermektedir. Pasta reklamının, kötü tarafı olarak sunulan reklamda, yılanlar, akbabalar, kemikler gösterilmekte, robotlar, arbaletler, ışık saçan gözler görülmektedir. Reklam üretilen otomobilin, üreticilerine hırlar bir tavır sergilemesiyle (motor sesi ve öne hareketle belirtilmiş) ve kendisine yönelen mızrağa karşı koymasıyla sonlanmaktadır. http://www.youtube.com/ watch?NR=1\&v=BQq_Rzn-yu0\&feature=fvwp (18.09.2014).

38 Üretimin anlatıldığı Skoda 10 reklamında, Skoda marka otomobilin kumdan heykeli yapılmaktadır. Her ayrıntısı özenle işlenen otomobilin üretiminin de ayrıntılı ve hassas şekilde yapıldığı çağrışımı verilmektedir. http://www.youtube.com/watch?v=EJCcbeVNUb8 (18.09.2014).

39 Bir Hindistan düğünü ile ilişkilendirilen Skoda 1 reklamında, düğün hazırlıkları ile otomobilin üretim aşaması ilişkilendirilmektedir. Üretim aşaması gösterilmeyen reklamda, düğün hazırlıklarında yapılması gerekenlerle, üretimden sonra yapılan kontrollerin kontrol işareti (check) konularak gösterilmesi bağlantısı kurularak otomobilin üretim sonucunda denetimden geçtiği anlatılmaktadır. http://www.youtube.com/watch?v=ifzMfk71n3Y (18.09.2014). 


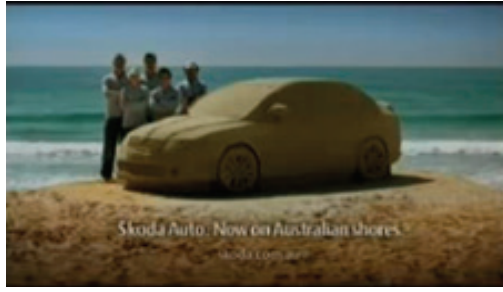

Reklam No. Skoda 10

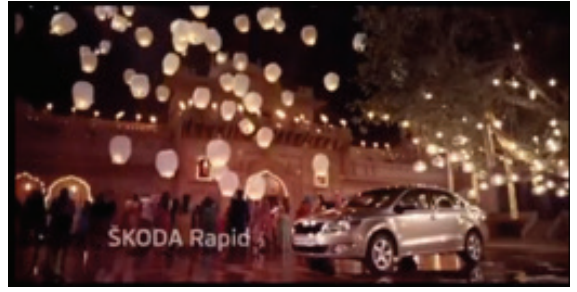

Reklam No. Skoda 1

\subsection{Rasyonel Tüketiciye Seslenen Reklamlar}

Skoda marka otomobil reklamlarında işlevsel temalar ön planda görünmektedir. Arabanın tasarımıyla ilişkilendirilen geniş hacmi sizi kucaklamasına, size ait her şeyi taşımasına olanak tanımaktadır. Skoda marka otomobil reklamları aracın özelliklerini sıralayarak rasyonel aklıyla tercih yaptığı farz edilen tüketiciye seslenmektedir. "Ürün seçiminde rasyonel olmanın gururu (yalnızca çoğunun yaptığını yapmak anlamında da olsa), artık var olmayan ele geçirilmesi imkânı bulunmayan teknik ya da toplumsal becerilerin sergilenmesine dayalı gururlandırıcı kendine saygının bıraktığı boşluğu doldurmaktadır (Bauman, 2003: 197). Tüketici rasyonel seçim yaptığı algısıyla haz alacak ve aracın özellikleriyle de sınıf atlamış olma hissini tadacaktır.

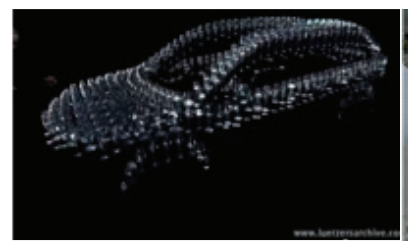

Reklam No. Skoda 2

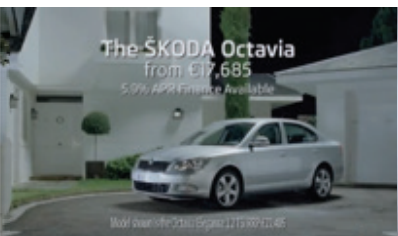

Reklam No. Skoda 3

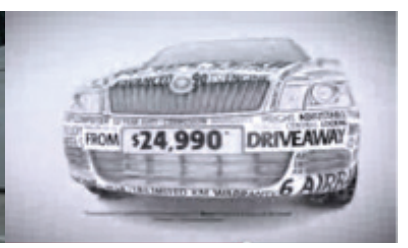

Reklam No. Skoda 4

Örneğin önce kadehlerin gösterildiği ve kadehlerle çalınan notalarla bir müzisyenin eseri eşliğinde sunulan reklamda (Skoda 2), arabanın tasarımı hacimle ilişkilendirilmiştir. Mükemmel harmonide 1865 litre bagaj hacmi sloganıyla sonlanan reklamda, tasarım işleve yönelik olarak sunulmaktadır. Bir diğer reklamda $\left(\right.$ Skoda $3^{40}$ ) işlevselliği ön plana çıkaran reklam kurgusunda fiyat-performans ilişkisi sunularak rasyonel alıcıya seslenilmektedir. Karakalem çalışması ile Skoda marka otomobilin ödülleri, bagaj hacmi, teknolojisi ve fiyatı gibi özelliklerinin anlatıldığı reklam (Skoda $4^{41}$ ), değeri her tarafına yazılı sloganıyla tamamlanmaktadır. Değerinin otomobilin her tarafında yazılı olması karakalem çalışmasında da verilmektedir. Verilen özellikler otomobilin çeşitli bölümlerine kalemle yazılmaktadır. Böylece rasyonel tüketiciye seslenen tüketici, otomobile sahip olduğunda baktığı her yerde otomobilinin değerini görebilecektir ve rasyonel seçim yapmanın gurunu yaşayacaktır.

40 Skoda 3 reklamında valizini hazırlayarak evden kaçan küçük kız çocuğu arkadaşıyla buluşmakta ve arkadaşının bisikletinin yanında yürümektedir. Valizin yere düşüp, içindekilerin dağıımasının ardından küçük kız, evlerinin önünde park halindeki otomobili görmektedir. Bazen daha geniş alana intiyaç duyabilirsiniz sloganıyla verilen reklamın sonunda otomobilin fiyatı belirtilmektedir. http://www.youtube.com/ watch?NR=1\&v=kxSYpFM3Ots (18.09.2014).

41 http://www.youtube.com/watch?v=aePM9mYg4E4\&NR=1 (18.09.2014). 


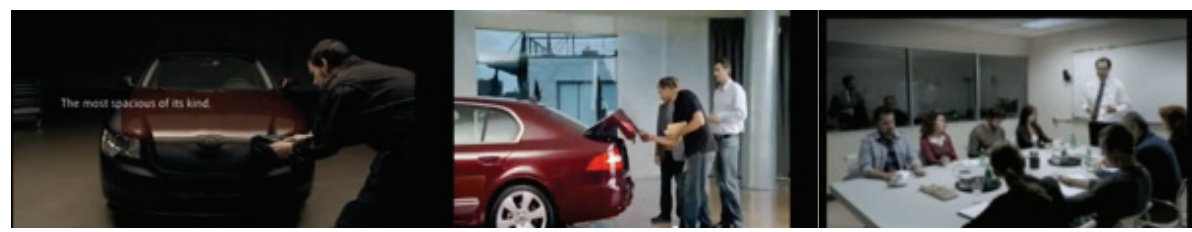

Reklam No. Skoda 7

Reklam No. Skoda 5

Reklam No. Skoda 17

Yine aynı şekilde araç özelliklerinin sunulduğu bir diğer reklamda (Skoda $7^{42}$ ), üzeri siyahla kaplanmış Skoda otomobilinin üzerindeki örtü aşama aşama kaldırılmakta ve her aşamada bir özelliği açıklanmaktadır. Karanlık sorularla boğuşan tüketiciye verilen yanıtlarla, rasyonel tercih yapması sağlanmaya çalışılmaktadır. Skoda $5^{43}$ reklamında da otomobilin özellikleri ile ilgili siyah ekranda sorular sorulmakta, her sorunun cevabı olarak Skoda otomobil gösterilmektedir. Yakıt tasarrufu, geniş bagaj hacmi, ödüller, güvenlik, yenilik gibiözelliklerin sıralandığı reklamda, soruların siyah ekranda verilmesi kafa karışıklı̆ına işaret etmektedir. Kafası karışık, sorularla boğuşan, içi kararmış bir şekilde sorularına yanıt arayan tüketici tüm cevaplarında Skoda'ya ulaşmaktadır. Sorularına aldığı yanıtlarla rasyonel tercihi yapmaktadır. Audi reklamlarına bakıldığında ürün özelliklerinin bu kadar açık olarak verilmediği, rasyonel tüketiciler yerine duygularıyla hareket eden hazcı tüketicilere seslendiği görülmektedir. Son olarak Skoda $17^{44}$ reklamında Skoda marka otomobilinin mükemmel olduğu belirtilmektedir. Her ne kadar işlevsel özellikleri verilmese de bir iş toplantısı kurgusuyla verilen reklamda otomobilin fetişleştirilmediği, rasyonel bir karar için mükemmel olduğu duygusu verilmeye çalışıldığı değerlendirilmektedir. Bu bağlamda Skoda marka otomobil reklamlarında da, Audi marka otomobil reklamlarındaki gibi net bir sınıf vurgusu olmasa da değer ve mükemmellik duygusunun verilmeye çalışıldığı anlaşılmaktadır.

\section{Sonuc}

Araştırma kapsamında incelenen otomobil reklamlarına genel olarak bakıldığında, her iki otomobil markasının da farklı gerekçelerle tüketiciye seslendiği görülmektedir. Reklamlardaki Audi marka otomobil bir fetiş nesnesi haline getirilmiş, arzulanan yakalanması gereken, sahip olunduğunda haz duyulan bir imajla sunulmuştur. Efsaneleştirilen otomobil, tüketiciye iz bırakan, unutulmayan bir sanat eseri olarak gösterilmiştir. Tüketiciye sahip olduğunda yaşatacağı hazzı vaat ediyor. Skoda markası daha çok rasyonel tüketicilere seslenmiştir. Reklamlarda fiyat verilmesi, işlevsel özelliklerin sıralanması tüketicinin rasyonel tercih yapmasına destek olmaktadır.

Audi marka otomobil reklamlarında fetiş nesnesi olarak sunulan otomobilin aynı zamanda tüketicinin kimliğinin ve yaşam tarzının oluşmasında ve sergilenmesinde bir araç olarak yansıtılığı görülmektedir. Bireyin farklı olma intiyacını gözeten ve biricikliğini pekiştiren reklam filmlerinde sunulan yaşam tarzları da farklılık göstermektedir. Audi marka otomobil reklamlarında kadın ve erkekler, yüksek ücretli maaşla çalışıı̆ı düşünülen, takım elbise giyen, anne olsa bile kendine (güzelliğine, cazibesine, farklılığına) özen gösteren birey olarak gösterilmektedir. Statü vurgusu, orta yaş beyaz erkek ve kadınların metropollerde gösterilmesiyle pekiştirilmektedir. Otomobil sürücüleri genel olarak tek başlarına seyahat eden, alış veriş yapan, çocuğunu okula

42 http://www.youtube.com/watch?v=AepLSLvylA8 (18.09.2014).

$43 \mathrm{http} / / / w w w . y o u t u b e . c o m / w a t c h ? N R=1 \& v=q j E s t H H K \_I s ~(18.09 .2014)$.

44 Skoda marka otomobilin gösterilmediği Skoda 17 reklam filminde otomobilin kusursuz olduğuna yönelik bir vurgu vardır. Otomobil sahipleri ile yapılan bir toplantıda ürünün daha iyi hale getirilmesi için yapılabilecekler sorulmakta, ancak değiştirilebilecek başka bir şey olmadığı belirtilmektedir. http://www.youtube.com/ watch?v=7SvjtoDUbwg (18.09.2014). 
bırakan ya da okuldan alan kadın ve erkeklerdir. Birey otomobili kullanmakla ya da ona sahip olmakla yaşadığı bütün aykırı duyguları tek başına deneyimlemektedir. Yaşanan duygular şüphe, heyecan, güç gibi duygulardır. Böylece kolektiflik duygusunun dışarıda bırakıldığı reklamlarda bireyin kendi kendine yetebilme hali ve bireyselliği vurgulanmış olmaktadır. Skoda reklamlarında verilen yaşam tarzı daha kolektif bir yapı sunmaktadır. İdeal mutlu aile tablosu çizilen reklamlarda otomobili genellikle aile reisi baba ya da eş kullanmakta, güç, ünlü olmak, zengin olmak yerine geleneksel ataerkil değerler ön plana çıkarılmaktadır. Otomobil sahibi iken yaşanan duygular da geleneksel değerlerle bağlantılı olarak, huzur, mutluluk, özgürlük ve heyecan olmakla beraber söz konusu duygular aile birlikte deneyimlenmektedir. Geleneksel değerlerle ifade edilen Skoda marka otomobilleri, kendini aile otomobili olarak konuşlandırdığı reklamlarında, geniş iç hacmiyle sevdiklerinizi taşıyan, onların güvenle seyahat etmesine olanak veren şekilde gösterilmiştir.

Her iki otomobil reklamında da ürünün yakıt tasarrufu farklı amaçlarla verilmiştir. Audi reklamlarında az yakıt tüketen otomobilin çevreye duyarlı olduğu vurgulanırken, Skoda reklamlarında bu durum kârılık ile ilişkilendirilmiştir. Skoda markasının satılmasıyla birlikte yaşadığı değişim ve dönüşümlerin etkisinin reklamlarda da yansımasını bulduğu Skoda markası simge değerine, araç yüzeyine Sennet'in tabiriyle 'altın kaplama'ya önem vermeye başlamıştır. Eğlencenin, iletişimin, yeniliğin ve sürüş deneyiminin vurgulandığı reklamlarla birlikte Skoda marka otomobilleri de gösterge değerleriyle ifade edilmeye ve rasyonel tercih yapan tüketici kitlesinin yanına yenilerini eklemeye başlamıştır.

Bütün reklamlar genel olarak değerlendirildiğinde markaların farklı sınıfsal konumdaki tüketicilere yönelik olarak üretildiği ve reklamlarda da bu durum meşrulaştırılarak otomobillerin bu şekilde algılanmasına yol açtığı anlaşıır olmaktadır. Reklamlarda gerçek kullanım değerlerini gizleyen ve kendi gerçekliklerini oluşturan otomobiller bir yerden bir yere götürme intiyacını karşılayacak salt ulaşım aracı olmaktan çıkmakta, çeşitli sembollerle özdeşleştirilerek sahte ihtiyaçlara gönderme yapmaktadır. Skoda markasının sınıf atlama vaadiyle orta sınıfa seslendiği ve reklamlarında orta sınıfın geleneksel değerlerini gösterdiği, Audi markası kadar belirgin şekilde sınıf, statü ve farklı kimlikler üzerine yoğunlaşmadığı görülmektedir. Lüks tüketim nesnesi olarak sunulan Audi markası haz, bireysellik, gösteriş, güç, aristokrasi gibi vurgularla üst sınıfa seslenmektedir. Bu açıdan bakıldığında reklamlarda verilen sembol ve değerlerin de Bourdieu'nun belirttiği sınıfsal beğenilere yönelik olarak sunulduğu değerlendirilmektedir. Tüketici kendi sınıfına uygun olan otomobili tüketerek reklamlarda verilen göstergeler aracılığıyla farkııı̆ını yaşayacak ve aslında kendi sınıfsal konumunu da pekiştirmiş olacaktır.

\section{Kaynakça}

Adorno Theodor W. ve Horkheimer Max (2010). Aydınlanmanın Diyalektiği. İstanbul: Kabalcı.

Atabek, Gülseren Şendur ve Atabek, Ümit, (2007). Medya Metinlerini Çözümlemek İçerik, Göstergebilim ve Söylem Çözümleme Yöntemleri. Ankara: Siyasal.

Aygün Cengiz, Serpil (2009). Modernizm Otomobil Kültürü ve Reklam. Ankara: Ütopya.

Baudrillard, Jean (2008). Tüketim Toplumu. Oğuz Adanır. (çev.). İstanbul: Ayrıntı.

Bauman, Zygmunt (2003). Yasa Koyucular ile Yorumcular. İstanbul: Metis.

Bauman, Zygmunt (2010a). Etiğin Tüketiciler Dünyasında Bir Şansı Var Mı?. Funda Çoban-İnci Katırcı. (çev.). Ankara: De Ki. 
Bauman, Zygmunt (2010b). Küreselleşme Toplumsal Sonuçları. Abdullah Yılmaz. (çev.). İstanbul: Ayrıntı.

Bocock, Robert (2009). Tüketim. İrem Kutluk. (çev.). Ankara: Dost.

Bourdieu, Pierre (1984). Distinction: A Social Critique of the Judgement of Taste. Harvard University Press.

Dağtaş, Banu (2009). "Reklamları Görmek: Reklam Metinlerinin Ait Olduğu Kültürler ve Egemen Form Olarak Tüketim Kültürü.” Reklamcılık: Bakmak ve Görmek. (der.) içinde. Ankara: Ütopya: 46-78.

Dağtaş, Banu ve Dağtaş, Erdal (2009). "Tüketim Kültürü, Yaşam Tarzları, Boş Zamanlar ve Medya Üzerine Bir Literatür Taraması.” Medya, Tüketim Kültürü ve Yaşam Tarzları, Türkiye Medyasından Örüntüler. (der. ) içinde. Ankara: Ütopya. 27-75

Featherstone, Mike (1996). Postmodernizm ve Tüketim Kültürü. İstanbul: Ayrıntı.

Güneş, Serkan (2012). "Türk Toplumu ve Otomobil.” SDÜ Fen Edebiyat Fakültesi Sosyal Bilimler Dergisi. (25): 213-230.

Harvey, David (2010). Postmodernliğin Durumu. İstanbul: Metis.

Jameson, Fredric (1994). "Postmodernizm ya da Geç Kapitalizmin Kültürel Mantığı" F. Jameson, J.-F. Lyotard, J. Habermas Postmodernizm. (der.) içinde. İstanbul: Kıyı.

Kasım, Metin (2005). "Görsel Bir İleti Olarak Basın Reklamlarında Fotoğrafın Kullanımı Örnek Olay: 2004 Yılı." Selçuk Üniversitesi Sosyal Bilimler Enstitüsü, Yayımlanmamış Doktora Tezi.

Sennett, Ricahard (2011). Yeni Kapitalizmin Kültürü. İstanbul: Ayrıntı.

Sennett, Richard (2002). Kamusal İnsanın Çöküşü. Serpil Durak ve Abdullah Yılmaz. (çev.). İstanbul: Ayrıntı. Williamson, Judith (2000). Reklamların Dili "Reklamlarda Anlam ve İdeoloji". Ahmet Fethi. (çev.). Ankara: Ütopya.

http://www.volkswagenag.com/content/wwcorp/content/en/the_group/production_plants.html. Erişim Tarihi: 03.01.2015. 